Page 1 of 2

\begin{tabular}{|c|c|c|c|c|c|c|}
\hline \multirow{3}{*}{$\begin{array}{l}\text { 2. ECN Category } \\
\text { (mark one) } \\
\text { Supplemental } \\
\text { Direct Revision } \\
\text { Change ECN } \\
\text { Temporary } \\
\text { Standby } \\
\text { Supersedure } \\
\text { Cancel/Noid }\end{array}$} & \multirow{3}{*}{$\begin{array}{c}{[]} \\
{[x]} \\
{[]} \\
{[]} \\
{[]} \\
{[]} \\
{[]}\end{array}$} & \multicolumn{2}{|c|}{$\begin{array}{l}\text { 3. Originator's Name, Organization, MSIN, } \\
\text { and Telephone No. } \\
\text { R. W. Jacobson, Tank Farm } \\
\text { Operations, Rl-09, 376-2957 }\end{array}$} & \multicolumn{2}{|c|}{$\begin{array}{l}\text { 4. USQ Required? } \\
\text { [] Yes }[X] \text { No }\end{array}$} & $\begin{array}{l}\text { 5. Date } \\
\text { March 19, } 1997\end{array}$ \\
\hline & & \multicolumn{2}{|c|}{$\begin{array}{l}\text { 6. Project Title/No./Work order No. } \\
\text { Tank Farm Restoration and Safe } \\
\text { Operation, Project W-314, } \\
\text { "Upgrade Scope Summary Report" } \\
\text { (USSR) }\end{array}$} & \multicolumn{2}{|c|}{$\begin{array}{l}\text { 7. Bldg./Sys./Fac. No. } \\
\text { Tank Farms }\end{array}$} & $\begin{array}{l}\text { 8. Approval Designator } \\
\qquad N / A\end{array}$ \\
\hline & & \multicolumn{2}{|c|}{$\begin{array}{l}\text { 9. Document Numbers Changed by this ECN } \\
\text { (includes sheet no. and rev.) } \\
\text { WHC-SD-W314-RPT-003, Rev } 1\end{array}$} & \multicolumn{2}{|c|}{$\begin{array}{l}\text { 10. Related ECN No(s). } \\
\text { N/A }\end{array}$} & $\begin{array}{l}\text { 11. Related PO No. } \\
\text { N/A }\end{array}$ \\
\hline \multirow{2}{*}{\multicolumn{2}{|c|}{$\begin{array}{l}\text { 12a. Modification Work } \\
\text { [] Yes (fill out Blk. } \\
12 \mathrm{~b} \text { ) } \\
\text { [X] No (NA Blks. 12b, } \\
12 c, 12 \mathrm{~d})\end{array}$}} & \multirow[t]{2}{*}{$\begin{array}{l}\text { 12b. Work Package } \\
\text { No. } \\
\text { N/A }\end{array}$} & \multicolumn{2}{|c|}{$\begin{array}{l}\text { 12c. Modification Work Complete } \\
\text { N/A }\end{array}$} & \multicolumn{2}{|c|}{$\begin{array}{l}\text { 12d. Restored to original Condi- } \\
\text { tion (Temp. or Standby ECN only) } \\
\text { N/A }\end{array}$} \\
\hline & & & \multicolumn{2}{|c|}{$\begin{array}{l}\text { Design Author ity/Cog. Eng ineer } \\
\text { Signature \& Date }\end{array}$} & \multicolumn{2}{|c|}{$\begin{array}{c}\text { Design Authority/Cog. Engineer } \\
\text { Signature \& Date } \\
\end{array}$} \\
\hline
\end{tabular}

14a. Justification (mark one)

Criteria Change $[X]$ Design Improvement []

As- Found

[] Facilitate const

[] Environnental

Const. Error/Onission

[]

Facility Deactivation Design Error/Omission

14b. Justification Details

Customer guidance, AGA studies/recommendations, engineering analysis, and emergent

information necissitate scoping adjustment.

15. Distribution (include name, MSIN, and no. of copies)

Distribution Sheet

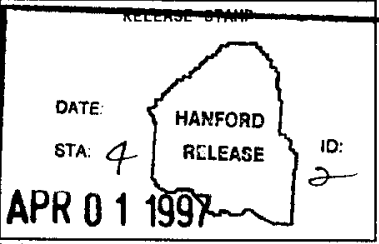




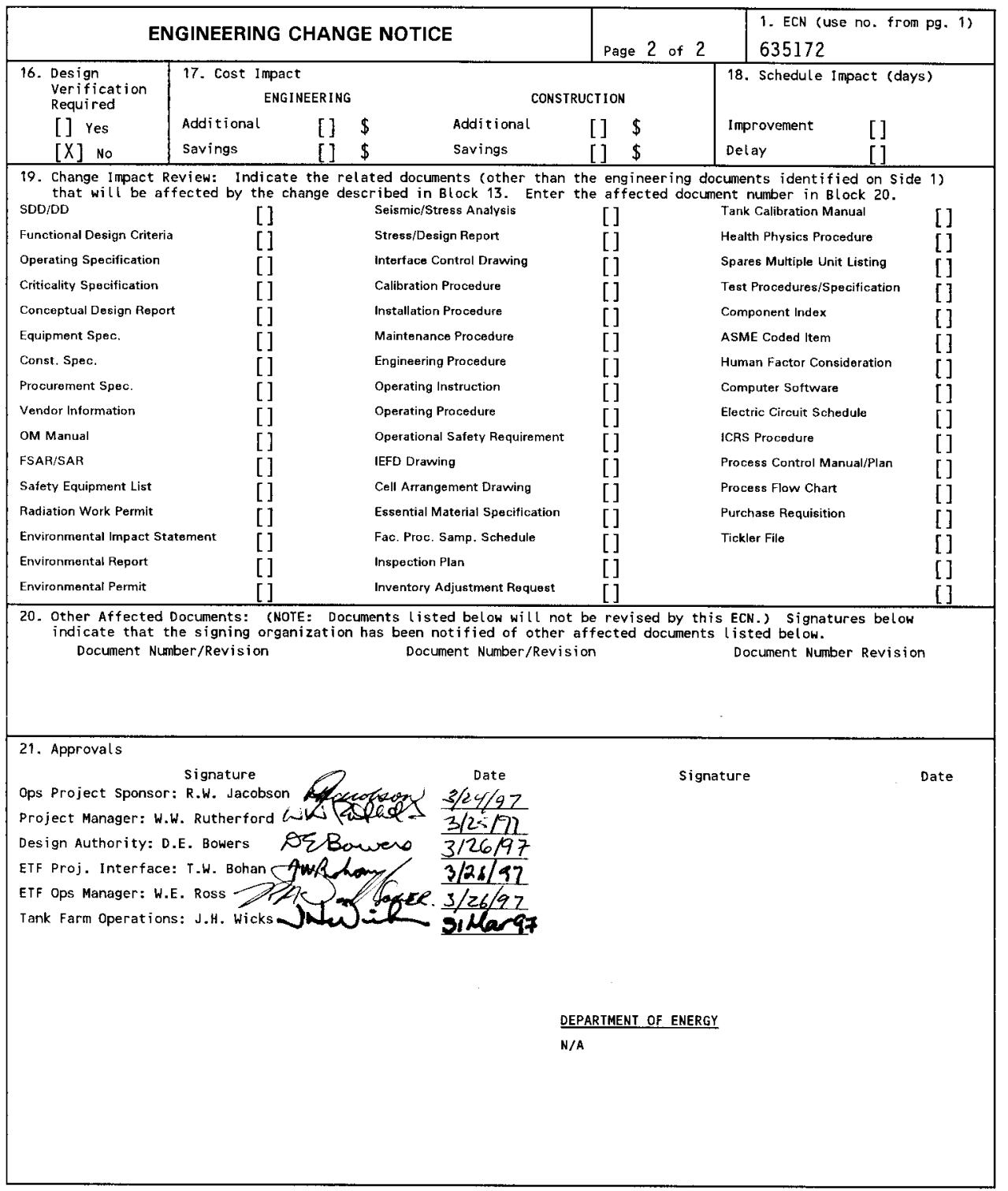




\title{
TANK FARM RESTORATION AND SAFE OPERATION, PROJECT W-314, UPGRADE SCOPE SUMMARY REPORT (USSR)
}

\author{
R. W. Jacobson \\ Lockheed Mart in Hanford Corporation, Rich1and, WA 99352 \\ U.S. Department of Energy Contract DE-AC06-96RL13200
}
EDT/ECN: 635172
UC: 2030
Org Code: 7000
B\&R Code: EW3120071
Charge Code: N311A
Total Pages: $6062 \mathrm{rmo} 4 / 1 / 47$

Key Words: The Tank Waste Remediation Systems (TWRS), Project $W-314$, Upgrade Scope Summary Report (USSR), Revision 2

Abstract: This revision to the Project $W-314$ Upgrade Scope Summary Report (USSR), incorporates changes to the project scope from Alternative Generation Analys is (AGA), customer guidance, and changing requirements. It defines the actual upgrades currently in scope, and provides traceability to the requirements and/or drivers.

TRADEMARK DISCLAIMER. Reference herein to any specific comercial product, process, or service by trade name, trademark, manufacturer, or otherwise, does not necessarily constitute or imply its endorsement, recommendation, or favoring by the United states Government or any agency thereof or its contractors or subcontractors.

Printed in the United States of America. To obtain copies of this document, contact: Document Control Services, P.O. Box 950, Mailstop H6-08, Richland WA 99352, Phone (509) 372-2420;

Fax (509) 376-4989.
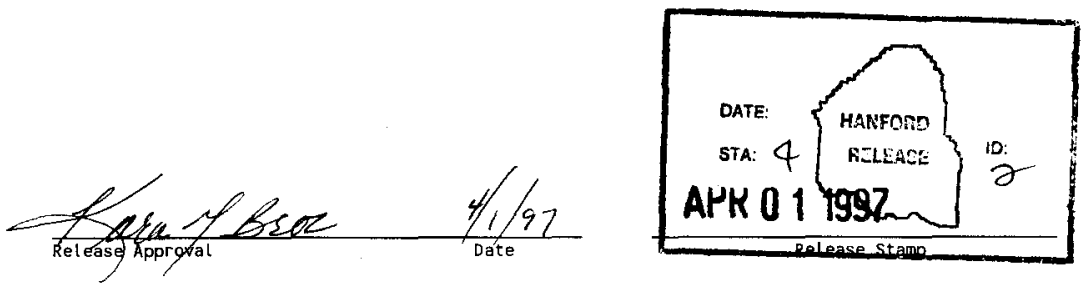

\section{Approved for Public Release}




\begin{tabular}{|c|c|c|c|c|}
\hline \multicolumn{2}{|r|}{ RECORD OF REVISION } & $\begin{array}{r}\text { (1) Document Nu } \\
\text { HNF-SD-W3 } 14 \\
003\end{array}$ & -RPT- & Page All \\
\hline \multicolumn{5}{|c|}{$\begin{array}{l}\text { (2) Title } \\
\text { Tank Farm Restoration and Safe Operation, Project W-314, } \\
\text { (USS) }\end{array}$} \\
\hline \multicolumn{5}{|c|}{ CHANGE CONTROL RECORD } \\
\hline (3) Revision & (4) Description of Change - Replace, Add, and Delete Pages & \multicolumn{3}{|c|}{ Authorized for Release } \\
\hline \multirow[t]{5}{*}{2 RS } & Full Revision; ECN 635172 & (5) cog. Engr. & \multicolumn{2}{|c|}{ (6) Cog. Mgr. Date } \\
\hline & & & & \\
\hline & $(7)$ & & & \\
\hline & Rev 0; EDT 614281; May 6, 1996 & & & \\
\hline & $\operatorname{Rev} 1$; ECN 635138; January 7,1997 & & & \\
\hline & & & & \\
\hline & & & & \\
\hline & & & & \\
\hline & & & & \\
\hline & & & & \\
\hline & & & & \\
\hline
\end{tabular}




\title{
U.S. DEPARTMENT OF ENERGY HANFORD SITE
}

\section{TANK FARM RESTORATION \\ AND SAFE OPERATIONS (TFRSO)}

PROJECT $\mathrm{W}-314$

UPGRADE SCOPE SUMMARY REPORT

\author{
March 24, 1997 \\ Prepared for: \\ U.S. Department of Energy \\ Richland Operations Office \\ Richland, Washington 99352
}

Prepared by:

Lockheed Martin Hanford Corporation

Post office Box 1500

Richland, washington 99352 


\section{HNF - SD - W314-RPT - 003}

Revision 2

TABLE OF CONTENTS

EXECUTIVE SUMMARY .........................

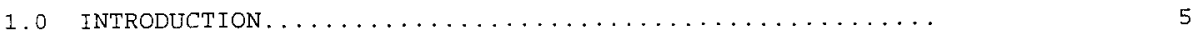

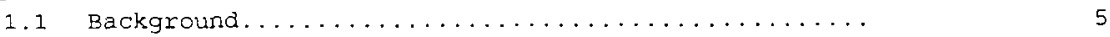

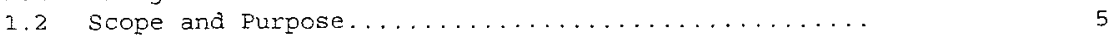

1.3 Document Interfaces......................

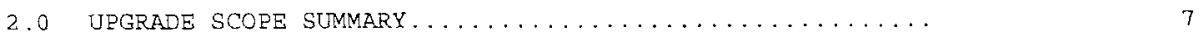

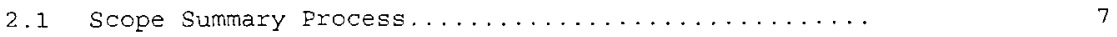

2.2 scope summary.......................... 8

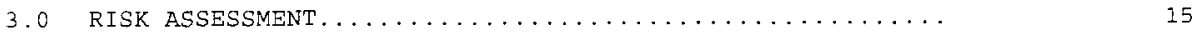

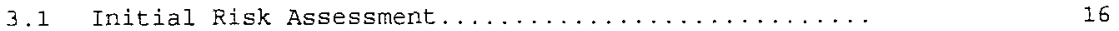

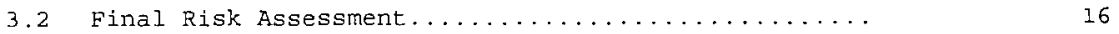

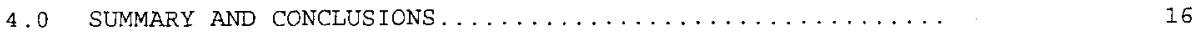

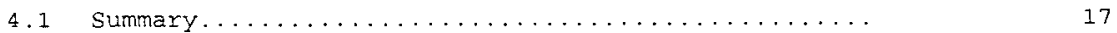

4.2 Conclusions............................ 17

APPENDIX

A. Acronyms and Abbreviations
B. References
C. Upgrade Scope Summary Table 


\section{HNF-SD-W314-RPT-003 \\ Revision 2}

\section{EXECUTIVE SUMMARY}

The Upgrade Scope Summary Report (USSR) is a sequential element document of the systems engineering process that is used to identify, in summary fashion, the work included in the $W-314$ project scope. It does not address systems engineering, testing, turnover, configuration, specifications, or other aspects of design, installation, and startup. The USSR document was initially prepared to define the scope on which to base development of a Conceptual Design Report (CDR) for Project $W-314$ upgrades. Subsequent changes to the project's scope are incorporated through revisions to the USSR.

Section I provides the Introduction for this document. This section contains general information on how and why the USSR was developed, the background information that was used to define the scope, and establish the basis of how the USSR is integrated into the document hierarchy for the W-314 Project. Section 2, Upgrade Scope summary, provides an overview of the Project W-314 scoping process and a listing of the specific scope elements current at the time of this revision. Section 3 presents a synopsis of the initial risk assessment efforts for this task and identifies the next iteration of risk assessment. Section 4 is the Actions and Requirements, which describes the future mission requirements, and conclusions of the scoping process.

The appendices provide supporting information. Appendix A lists and identifies the acronyms and abbreviations contained in this document. Appendix B provides a listing of references germane to the USSR effort. Appendix $C$ provides a crosswalk from the specific scope items in the USSR to the requirement or driver that determined inclusion in the scope.

Significant changes to Project $W-314$ scope identified by this revision to the USSR include:

- Deletion of the new transfer line between 241-A-A valve pit and the 241AW-A valve pit based on re-evaluation of waste transfer project needs.

- Adding a new transfer line between 241-AZ-01A and 241-AZ-02A Pump Pits as identified by "Alternatives Generation and Analysis for Phase I Privatization Transfer System Needs, WHC-SD-WM-TI-750, Rev. 0. 


\section{HNF-SD-W314-RPT-003 \\ Revision 2}

- Delete all 244-A DCRT upgrades and replacement of transfer line SN-216 as defined by the USSR, Rev 1, and incorporate deactivation of existing 244-A DCRT components and transfer line SN-216 in a configuration to support future deactivation of the facility per guidance in letter: J. $\mathrm{K}$. MCClusky, RL, to H. J. Hatch, FDH, "Decision Document for 244-A Double Contained Receiver Tank (DCRT) Utilization," 96-WSD-319, dated November 27. 1996.

- Add relocating the east termination point of the cross-site transfer lines from 244-A DCRT to a new diversion box in AN Tank Farm per "Alternative Generation and Analysis Report for 244-A DCRT Utilization," WHC-SD-W314-AGA-006, Rev 0 .

- Add over pressure protection for the cross-site transfer line in the new diversion box in AN Tank Farm, and install two transfer lines downstream of the diversion box going to $A N-A$ and $A N-B$ valve pits respectively, per guidance in letter: J. K. McClusky, RL, to H. J. Hatch, FDH, "Decision Document for 244-A Double Contained Receiver Tank (DCRT) Utilization،" 96-WSD-3I9, dated November 27, 1996.

- Delete leak detection pit (LDP) upgrades not related to level indication, and cap the process line nozzles in the associated pit per guidance in letter: J. E. Kinzer, RL to M. Wilson, Ecology, "Discontinuing Leak Detection Pit (LDP) Equipment Monitoring for Double-Shell Tanks (DST), "96-WSD-150, dated September 26, 1996. 


\subsection{INTRODUCTION}

This section provides general information on how and why the USSR was developed, identifies the background information that was used to establish the scope, and presents an explanation of how the USSR fits into the document hierarchy for the $\mathrm{W}-314$ Project.

\subsection{Background}

The mission of the Tank waste Remediation System (TWRS) Program is to store, treat, and immobilize highly radioactive tank waste in an environmentally sound, safe, and cost-effective manner. Within this program, "Tank Farm Restoration and Safe Operations" (TFRSO), Froject W314, has been established to provide major upgrades in the areas of instrumentation and control, tank ventilation, waste transfer, and electrical distribution for existing tank farm facilities.

The purpose of the W-314 Project is to restore and/or upgrade existing Hanford Tank Farm facilities and systems to ensure that the Tank Farm infrastructure will be able to support the continued safe management of tank waste, and support known future requirements. The capital improvements provided by this project will increase the margin of safety for Tank Farms operations, and will aid in aligning affected Tank Farm systems with compliance requirements from applicable, state, Federal, and local regulations. Secondary benefits will be realized subsequent to project completion in the form of reduced equipment down-time, reduced health and safety risks to occupational workers, reduced operating and maintenance costs, and minimization of exposure to the environment from radioactive and/or hazardous material releases.

\subsection{Scope and Purpose}

The USSR is a key element required for defining the scope of Project W314 . The initial USSR, with DOE-RL comments incorporated, was released on May 16, 1996. This provided the initial scope for the Conceptual Design Report (CDR), WHC-SD-W314-CDR-001, Rev 0 . 
HNF - SD-W314-RPT-003

Revision 2

Subsequent to this, additional information was identified to help clarify the scope. Revision 1 of the USSR represented a refinement of the project scope and supporting requirements from which the CDR, Revision 1 , was developed.

Revision 2 of the USSR incorporates changes identified by engineering studies, documented requirements interpretations, operational concepts, and newly developed technical specifications. This revision will provide the basis for revising the project cost and schedule baselines currently reflected in the TWRS Multi-Year Work Plan (MYWP).

\subsection{Document Interfaces}

The SE-SOW directed the preparation of certain documents in support of the systems engineering process for Project $W-314$, including the "Facility Assessment Summary Report" (FASR) WHC-SD-W314-ES-023, Rev 0, the USSR, and CDR.

The FASR correlates the data gathered to describe the existing conditions and required upgrades, and the definition of the upgrade work scope. Input documents include (among others) the Mission Analysis Report, Condition Assessment Surveys, Resource Allocation Sheets, and the Project $W-314$ Preliminary Design Requirements Document (PDRD). The FASR provided the initial data used for development of the preliminary Upgrades scope summary Report.

The W-314 FASR was prepared as a summarized report that documents the process used to determine acceptability or deficiency status of the systems, subsystems and/or components appraised during the initial Tank Farm systems assessments. The task involved the utilization of both historical and real-time evaluations to determine the status and conditions of the systems, subsystems, and components that could fall within the $W-314$ project. This systems assessment overview included walkdowns of the pertinent facilities, interviews, studies, and evaluations as needed to define the requirements for upgrades.

The USSR provides a link between the evaluation of existing conditions and required upgrades as defined by the FASR, emergent 
HNF-SD-W314-RPT- 003

Revision 2

issues, and identified future requirements. The CDR translates the general scoping identified in the USSR into individual scope for structure/system/component (SSC) upgrades and provides the initial basis for developing project cost and schedule baselines.

The cost and schedule information identified in the CDR represent the initial Project $\mathrm{W}-314$ baselines. Any adjustments to these baselines will be managed using applicable change control procedures and reflected in the TWRS Multi-Year Work Plan.

\subsection{UPGRADE SCOPE SUMMARY}

The systems inspections and assessments conducted for the TFRSO Project provided the information utilized as the basis of the FASR. Emergent requirements, identified future needs, and further investigation into data obtained during the assessments have resulted in scope beyond that developed from the FASR. This revision to the USSR incorporates the scope changes currently identified for project $W-314$.

\subsection{Scope Summary Process}

The primary objectives of the system assessments were to determine if the functionality of existing systems is sufficient to fulfill the mission requirements defined in the Preliminary Design Requirements Document (PDRD) and to determine if the life expectancy of the existing systems would be sufficient for the mission duration. The PDRD defines the system functionality required to meet the mission for a duration of 35 years. Tank Farm infrastructure systems addressed by the PDRD are:

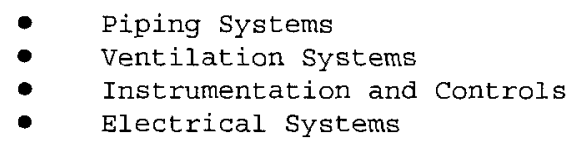

The screening process conducted during the development of the FASR identified two types of requirements and related scopes of work; those that are to be included in the $W-314$ Project, and those to be excluded from the W-314 Project (the 'Other' category) The 
initial elements of work to be included in the $\$-314$ Project scope are presented in detail in the Functions Assessment Tables (FATs) included with the initial assessment reports.

Revision 1 included future requirements, trade study results, and emergent information that was available. The PDRD was formalized into the Design Requirements Document (DRD) utilizing this new information.

This revision to the USSR adjusts the $\mathrm{W}-314$ scope to incorporate Alternative Generation Analysis (AGA) findings, revised requirements resulting from Project Development Specifications (PDS), clarified regulatory requirements, and operations functional requirements as identified by Project Design concepts (PDC).

\subsection{Scope Summary}

The criteria used to define the scope of $W-314$ are as follows:

1. Systems shall be provided and/or upgraded to support the TwRS Manage Tank Waste (MTW) function and Tri-Party Agreement (TPA) milestones. Formally identified requirements necessary for future needs will be evaluated for inclusion in W-314 as appropriate.

2. Systems shall be designed in such a manner as to ensure safety in the following areas:
a. Off-Site Exposure
b. Environment Exposure
c. Personnel Safety
d. System safety

3. Systems shall perform such that the tank farm mission to Manage Tank waste is satisfied (i.e. meets requirements documented in the PDRD). 
4. Systems shall be capable of performing requirements for the duration of the mission.

5. Systems shall comply with legal/regulatory constraints as documented in the DRD

6. Systems shall be capable of efficient operation as measured in terms of:

\section{a. Reliability, Availability, Maintainability \\ b. Operability}

7. System modification and replacement decisions shall consider applicable life cycle costs in the areas of:
a. Design
b. Construction
c. Operations
d. Support

\subsubsection{Piping scope}

The Project $W-314$ scope of work for piping covers the following:

- All central pump pits and valve pits/diversion boxes along the waste transfer routes for double-shell tanks will be cleaned, decontaminated, and upgraded with a protective coating in order to meet all decontaminability and/or regulatory compliance criteria. The protective coating will be applied to (as a minimum): Valve pits 241-AN-A, $A N-B, A-A, A-B, A W-A, A W-B, A X-A, A X-B$, and pump pits $241-$ AN-01A, AN-02A, AN-03A, AN-04A, AN-05A, AN-06A, AN-07A, AZ$01 \mathrm{~A}, \mathrm{AZ}-02 \mathrm{~A}, \mathrm{AY}-01 \mathrm{D}, \mathrm{AY}-02 \mathrm{~A}$, and $\mathrm{AY}-02 \mathrm{D}$.

- New manifold jumper arrangements shall be installed in selected valve and pump pits to provide a greater degree of flexibility in transfer routes, reduce jumper change out and maintenance requirements, and minimize personnel exposure. Valves utilized in the manifolds 
shall lend themselves to both manual operation and automatic operation via motors outside the pit. Motor installation is not included in $\mathrm{W}-314$. Pits receiving manifold jumper arrangements will include: Valve pits $A N-A, A N-B, A-A, A-B, A X-A, A X-B$; and pump pit AZ-02A

- New transfer lines compatible with the new cross site transfer Iine and the waste disposal privatization needs will be provided to support projected waste transfer operations between the following locations:

- Valve pit AN-B to pump pit AZ-02A

- Pump pit $A Z-02 A$ to valve pit $A X-B$

- Pump pit az-02A to pump pit az-01A

- Cross-site transfer lines west of 244-A DCRT (tiein location to be determined) to a new diversion box to be provided by $\mathrm{W}-314$ in, or adjacent to, the $\mathrm{AN}$ Tank Farm

- New diversion box (provided by $w-314$ ) to the AN-A and AN-B valve pits (two lines required)

- Replace the following existing transfer piping:

- Line SN-213/200

- Line SL-502

- Line SL-504

- Installation of a new diversion box in AN Tank Farm. This diversion box will provide the east termination point for the cross site transfer lines, incorporate over pressure protection for the cross-site transfer lines, facilitate installation of new transfer lines to $A N-A$ and $A N-B$ valve pits, and provide an installed rigid jumper and connections to enable cross site transfers to go direct to Tank AN-103. In addition, this diversion box will provide the ability to transfer waste into the cross-site transfer lines from East Tank Farms.

- Permanently cap all waste transfer lines to 244-A DCRT. 


\subsubsection{Piping Assumptions}

1. Jumper manifold upgrades for the AW Tank Farm valve pits are planned for Project $W-454$.

2. Line $S L-180$ from SY-A valve pit to $S Y-B$ valve pit is being replaced by Project $W-211$.

3. Installation of the new valve pit and lines on the SN-650 line to support Privatization will be the responsibility of the Retrieval Program.

4. The final configuration will result in continuous 3" transfer system from the cross-site transfer line to the A-B valve pit.

5. Pit nozzles not hooked to manifolds shall be process blanked for those to remain functional, and permanently blanked for those being removed from future service.

\subsubsection{Ventilation scope}

The scope of work includes upgrading the ventilation systems for select DSTs and the 244-S DCRT. The ventilation systems will include seal pot and drainage systems, and filtration systems. The new ventilation systems will be modular in design to facilitate modifications in support of gaseous effluent treatment requirements as identified in the DRD and other requirements documentation. Specific upgrades are:

- Primary ventilation systems for:

- AN Farm

- AP Farm

- AW Farm

- Annulus ventilation system for SY Farm.

- Complete ventilation system for the 244-S DCRT.

\subsubsection{Ventilation Assumptions}

1. The design will be modular to the extent that special 
effluent treatment devices (such as absorbers for organics and/or ammonia control) can be easily connected in the future to support possible waste storage and/or transfer situations.

2. The ventilation design will assume that existing equipment that is taken out of service will be removed, where practicable, and the new equipment located in a nearby area utilizing existing ducting where possible.

\subsubsection{Instrumentation and Control Scope}

The scope of work includes new and/or upgraded instrumentation for tank monitoring for all double shelled tanks (DST's) and the 244-S DCRT, tank and waste transfer leak detection system upgrade, TMACS and SACS upgrades for information management system functions, the master pump shutdown system upgrade, and selected single shell tank (SST) signals. Some instrumentation and control upgrades will be, or have been, performed by other activities and won't be included in $\mathrm{W}-314$ scope.

The following upgrades provide the monitoring and control functions required:

- Replace the existing method of annulus leak detection in DST's with better technology.

- Replace the specific gravity-weight factor (SpG-WF) method of annulus leak detection in the DCRT with better technology.

- Upgrade the constant air monitor (CAM) annulus leak detectors in DST's and DCRT with new models.

- Replace the SpG-WF method of determining DST leak detection pit level with better technology. This method will be applied to a dry pit.

- Alarm DST leak detection pit high liquid level. 
- Alarm high liquid level in DST's.

- Replace existing clean out box leak detection systems with an operationally testable system.

- Replace all existing transfer system leak detectors with an operationally testable design in the DST farms and DCRT transfer pits. (Pipe encasements, valve/pump pits, diversion boxes, etc.)

- Verify waste transfer routing through the use of valve position indicators (valve Pits $A N-A, A N-B, A P, A W-A, A W-B$, $A-A, A-B, A X-A, A X-B$; Pump Pits AN-01A through 07A, AP-01A, AP-04A, AP-02A, AP-02D, AW-0IA, AW-04A, AW-05A, AY-02A, AZ01A, AZ-02A; Sluice Pit AZ-02B; and SY Pits SY-A, SY-B, SY$01 \mathrm{~A}$, and $S Y-02 A$ as a minimum); and/or pipeline flow monitoring (tanks AN-101, 102, 103, 104, 105, 106, 107; AP$101,102,104 ; A W-101,104,105 ; A Z-101,102 ; A Y-102 ;$ and SY-101, 102 as a minimum).

- Upgrade the MPS system to use operationally testable components and to replace the relay-based approach in the DST farms, 242-A Evaporator, and SST farms as specified.

- Include provisions for the privatization contractors to tie their vitrification plant transfer pumps into the MPS system to facilitate transfers back to the farms.

- Move the master pump shutdown panel out of the 242-s evaporator building.

- Install raw water flow measurements for DST's and DCRT service pits, including turbine flowmeters in the $A N, A P$, $A W, A Y$, and $S Y$ service pits to support waste disposal privatization.

- Install raw water radiation measurement capability (backflow detection) at the $244-S$ DCRT service pits. 
HNF - SD-W314-RPT- 003

Revision 2

- Provide leak detection for new piping.

- Upgrade tank waste temperature, and liquid level measurement in selected DST's and the DCRT (upgrades performed by other activities won't be included).

- Upgrade tank primary vapor space pressure measurement in DST's and the DCRT.

- Upgrade primary ventilation train pre-filter and HEPA filter differential pressures, exhaust temperature, and exhaust heater differential pressure for the 244-S DCRT, and all DST farms except $A Y$ and $A Z$.

Install the WHC "Gaseous Effluent Monitoring System" at the $A W, A N$ and AP primary ventilation exhaust stack and connect existing SY tank farm "Gaseous Effluent Monitoring System" to a remote monitor.

- Input existing DST farm annunciated signals ("Panalarm") into the centralized Temperature Monitoring and Control System (TMACS).

- Replace the existing "Game-Well" remote alarm monitoring system with alarm displays in the DST farms.

- Connect selected existing alarms from miscellaneous hazardous facilities and SST farms for input to the TMACS.

- Move selected monitor and controls from the $242-S$ control room ( $W-314$ only addresses farm signals, not buildings, and will not ensure the associated equipment is operational).

\subsubsection{Electrical scope}

The scope of work for electrical includes upgrades to electrical equipment and wiring as required throughout the DST farms, selected SST farms, and the 244-S DCRT. These upgrades will 
HNF - SD-W314-RPT- 003

Revision 2

include the following:

- Replacement of existing motor control centers (MCC's) and vent and heater control panels with new units in the 241-AY and 241 AZ Tank Farms.

- Upgrade and/or provide backup power capability for the primary ventilation system and stack monitors for Tank Farms 241-AN, $A P$, and $A W$.

- Provide a new pad-mounted $13.8 \mathrm{kV}$ transformer and system to supply power to $244-\mathrm{S}$.

- Bring SST power systems to code with standardized grounding to support existing lights, service outlets, and miscellaneous instrumentation such as TMACS.

- Install spare main circuit breakers for AN, and AW Tank Farms.

- Provide cathodic protection for new transfer piping.

- Provide freeze protection for seal pots, drainage systems, and piping (if required) installed by $\mathrm{W}-314$.

\subsection{RISK ASSESSMENT}

A preliminary Risk Assessment was conducted in support of the initial assessment activities. The risk assessment was concerned with the credibility of the system assessment, particularly as it related to the determination of the scope of the Project $\mathbb{W}-314$. Key factors in evaluating the credibility of the assessment included the methodology of the assessment, the degree of confidence in the conclusions of the assessment for specifying the condition of the tank farms, and the risk these conditions posed to the project. The risk to the project would be manifested as scope change later in the design, with attendant cost and schedule impacts. 
HNF - SD - W3 14-RPT- 003

Revision 2

\subsection{Initial Risk Assessment}

The risk assessment methodology used to develop the Risk Report was generally based on expert opinion, augmented by consideration of key risk indicators. Information acquired in response to the questions posed by the risk indicators is a direct indication of the credibility of the process being examined. Eor example, a process that commences with a well documented, thorough plan which has been promulgated to all participants is more likely to produce credible results than one which develops as the action is conducted. This does not stipulate that the latter approach is not without some value. The risk assessment for the TFRSO initial assessment was conducted in a manner that maintains cognizance of the fact that the material condition of the tank farm is generally well known. Thus the primary purpose of the system assessment, as it relates to the Project $W-314$, is to assess the condition of the tank farm systems, structures, and components specifically as to their capability to satisfy requirements of the PDRD.

\subsection{Final Risk Assessment}

The second phase of Risk Assessment will be performed in accordance with the "Project Execution Plan for Tank Farm Restoration and Safe operation, Project W-314", HNF-SD-W314-PMP001 . Documentation of the results will be in accordance with approved procedures.

\subsection{SUMMARY AND CONCLUSIONS}

The scope definition presented in this document represents a programmatic determination of what tank farm upgrades will be achieved within the scope of Project $W-314$. Approved changes have been incorporated into this USSR to maintain a current summary listing of the project's scope. 
HNF - SD-W314-RPT-003

Revision 2

\subsection{Summary}

The USSR provides the basis for development of the Project W-314 conceptual design and subsequent detailed design activities. The information provided in Section 2 identifies the scope elements for the W-314 Project. Additional information will be developed (via studies, engineering analyses, etc.) during CDR development to further define and clarify scope elements to support definitive design activities.

\subsection{Conclusions}

Based on an evaluation of the information contained in the DRD and presented in the FASR, and information developed after the FASR, the following have been concluded:

1. The DRD provides the upper level requirements that define the scope for the w-314 Project.

2. The scope defined in this USSR is necessary to support the TWRS Manage Tank Waste mission, initial privatization activities, and initiation of detailed design activities.

3. The scope of the $\mathrm{W}-314$ Project may be further defined to reflect emergent information, changing requirements, or regulatory interpretations. This is not expected to significantly affect the conceptual design of the project. 
HNF - SD - W314-RPT-003

Revision 2

\section{APPENDIX A \\ ACRONYMS AND ABBREVIATIONS}

$\begin{array}{ll}\text { CAM } & \text { Constant Air Monitor } \\ \text { CDR } & \text { Conceptual Design Report } \\ \text { DCRT } & \text { Double Contained Receiver Tank } \\ \text { DOE-RL } & \text { Department of Energy, Richland Operations Office } \\ \text { DRD } & \text { Design Requirements Document } \\ \text { DST } & \text { Double Shell Tank } \\ \text { FASR } & \text { Facility Assessment Summary Report } \\ \text { FAT } & \text { Functions Assessment Table } \\ \text { IMS } & \text { Information Management System } \\ \text { LDP } & \text { Leak Detection Pit } \\ \text { MAR } & \text { Missions Analysis Report } \\ \text { MCC } & \text { Motor Control Center } \\ \text { MTW } & \text { Manage Tank Waste } \\ \text { PDC } & \text { Project Design Concept } \\ \text { PDRD } & \text { Preliminary Design Requirements Document } \\ \text { PDS } & \text { Project Development Specification } \\ \text { RAS } & \text { Resource Allocation Sheets } \\ \text { SACS } & \text { Surveillance Automated Computer System } \\ \text { SE } & \text { Systems Engineering } \\ \text { SOW } & \text { Statement of Work } \\ \text { SSC } & \text { Structure/System/or Component } \\ \text { SST } & \text { Single Shell Tank } \\ \text { TFRSO } & \text { Tank Farm Restoration and Safe Operations } \\ \text { TMACS } & \text { Temperature Monitoring and Control System } \\ \text { TWRS } & \text { Tank Waste Remediation System } \\ \text { TPA } & \text { Upgrade Scope Summary Report } \\ \text { USSR } & \end{array}$




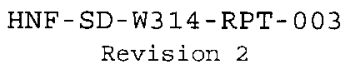

\section{APPENDIX B REFERENCES}

- WHC-SD-W314-ES-023, Rev 0, "Facility Assessment Summary Report" (FASR)

- WHC-SD-W314-ES-018, Rev 0, "DST and DCRT Instrument and Control Systems, Initial Assessment" (Acree 1995)

- WHC-SD-W314-ES-020, Rev 0, "DST and DCRT Rank Farm Electrical Distribution Systems Initial Assessment" (Golberg 1995)

- WHC-SD-W3 I4-ES-021, Rev 0, "Initial Assessment Report for Mechanical Systems Upgrade" (Mattichak 1995)

- WHC-SD-W314-ES-022, Rev 0, "Initial Assessment Report, HVAC Systems" (Kriskovich 1995)

- WHC-SD-W314-DRD-002, “Design Requirements Document” (DRD)

- WHC-SD-W314-ANAL-005, Rev 0, "Alternative Generation and Analysis Report for Pit Lining Systems", dated March 1, 1996

- WHC-SD-W314-AGA-006, Rev 0, "Alternative Generation and Analysis Report for 244-A DCRT Utilization", dated September 26, 1996

- WHC-SD-WM-TI-750, Rev 0, "Alternative Generation and Analysis for Phase I Privatization Transfer System Needs", Dated May 1, 1996

- Letter, J. E. Kinzer, RL, to M. Wilson, Ecology, "Discontinuing Leak Detection Pit (LDP) Equipment monitoring for Double-Shell Tanks (DST)," 96-WSD-150, dated September 26, 1996

- Letter, J. E. Kinzer, RL, to H. J. Hatch, FDH, “Project W-314, Tank Farm Restoration and Safe Operations (TFRSO), Project Scope Direction for Fluor Daniel Hanford, Inc. Contract Number DE-AC106-96RL13200," 96-WSD-244, dated October 11, 1996

- HNF-SD-W314-PMP-001, Rev 0, "Project Execution Plan for Tank Farm Restoration and Safe Operation, Project W-314," dated December 6, 1996.

- Letter, J. K. McClusky, RL, to H. J. Hatch, FDH, "Decision Document for 244-A Double Contained Receiver Tank (DCRT) Utilization," 96-WSD-319, dated November 27, 1997. 
- HNF-SD-W314-PDS-001, "Project Development Specification for Transfer Piping"

- HNF-SD-W314-PDS-002, "Project Development Specification for Valve Pit Manifolds"

- HNF-SD-W314-PDS-003, "Project Development Specification for Pit Leak Detection"

- HNF-SD-W314-PDS-004, "Project Development Specification for Master Pump Shutdown System"

- HNF-SD-W314-PDS-005, "Project Development Specification for Special Protective Coating" 


\begin{tabular}{|c|c|c|c|}
\hline Section & Category & Description & Requirement \\
\hline $\begin{array}{l}\text { USSR } 2.2 .1 \\
\text { TWRS SE } 4.2 .1 \\
\text { W-314 SE } \\
4.2 .1 .3\end{array}$ & Piping & $\begin{array}{l}\text { Install new manifold jumper arrangements in selected valve and } \\
\text { pump pits to provide a greater degree of flexibility in transfer } \\
\text { routes, reduce jumper change out and maintenance requirements, } \\
\text { and minimize personnel exposure. Values utilized in the manifolds } \\
\text { shall lend themselves to both manual operation and atheistic } \\
\text { operation via moors outside the p.t. } \\
\text { - Valve pits AN-A, AN-B, A-A, } \\
\text { A-B, AX-A, and AX-B } \\
\text { - Pump Pit AZ-02A }\end{array}$ & $\begin{array}{l}\text { Safety Not required for safety. } \\
\text { Compliance 10CFR61.41, ALARA. } \\
\text { Privatization Supports AN and AP privatization requirements. In } \\
\text { order to meet TPA milestones the Arena Model shows the need } \\
\text { for simultaneous, multiple transfers and the ability to quickly } \\
\text { setup new transfer routes. } \\
\text { Conduct of Operations Reduce personnel exposure, operating. } \\
\text { and maintenance costs by eliminating pit entry for jumper cliange } \\
\text { out. Support privatization and accelerate the tank farms closure } \\
\text { by about three years. }\end{array}$ \\
\hline \multicolumn{4}{|c|}{$\begin{array}{l}\text { Additional Information } \\
\text { 1. } \\
\text { Ref: WHC-SD-W454-CDLR-001, Rev. 0 (Draft), Conceptual Design Letter Report for Project W-454, AW Jumper Manifold Upgrade, dated January } 1996 . \\
\text { Discussion: Jumper manifolds in the AW Valve Pits were shown to provide ALARA benefits by reducing worker radiation exposure due to changing transfer routes. In } \\
\text { addition, a Life-Cycle Cost Analysis showed a payback of the costs associated with Project W-454 in approximately five years. }\end{array}$} \\
\hline
\end{tabular}




\begin{tabular}{|c|c|c|c|}
\hline Section & Category & Description & Requirement \\
\hline $\begin{array}{l}\text { USSR } 2.2 .1 \\
\text { TWRS SE } 4.2 .1 \\
\text { W-3I4 SE } 4.2 .1 .3\end{array}$ & Piping & 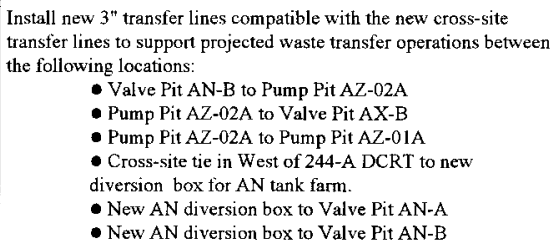 & $\begin{array}{l}\text { Safety Not required for safety. } \\
\text { Compliance Addresses } 244-A \text { DCRT and SN-216 compliance } \\
\text { issues. } \\
\text { Privatization Supports AN and AP privatization requirements. } \\
\text { Conduct of Operation Add waste routing flexibility. Allow } \\
\text { transfer lines to operate at full capacity and avoid premature line } \\
\text { failure due to pipe erosion. Support accelerated tank farms } \\
\text { closure. }\end{array}$ \\
\hline
\end{tabular}

Additional Information

1. Ref: WHC-SD-WM-TI-750, Rev, O, "Alternative Generation and Analysis for Phase I Privatization Transter System Needs."

Discussion: The preferred options for the Privatization transfer system require the replacement and upgrade of 2 "SL-502 to 3 -inch, and replacement of 3 "SN-213/200. The upgrade of SL-502 is required to obtain acceptable head requirements for transfers from the 241-AY Farm to the Privatization tanks AP-106 and 108 . The replacement of $\mathrm{SN}-213 / 200$ is required to increase the design pressure limit of the transfers from the $241-\mathrm{AN}$ and $241-\mathrm{AZ}$ Farms. The existing SN-213/200 has a design pressure limit of $230 \mathrm{psi}$, which is below the pressure required to transfer waste from the $241 \mathrm{AN}$ Farm to the 24l-AP Farm, and from the 24l-AZ Farm to the Privatization contractor's site.

2. Ref: WHC-SD-RE-TI-148, Rev. 0, "Metallurgical Analysis of Leak Failure of 241-A-B Valve Pit Jumper."

Discussion: The same transfer that caused the failure of the 241-A-A Valve Pit Jumper and line SN-233 is believed to have reduced the wall thickness on transfer lines SN216. Transfer line SL-503 has already failed and is currently being replaced. Controlled photographs numbered $8501893-6 \mathrm{CN}$. 8503999-6CN, and $850399-4 \mathrm{CN}$ provide visual affirmation of piping degradation due to corrosion along the route serviced by these lines

3. Ref: HNF-SD-W314-AGA-006, Rev 0; "Alternative Generation and Analysis Report for 244-A DCRT Utilization"

Discussion: This AGA reached the conciusion that relocating the termination point for the cross-site transter line to AN Tank Farm and taking the 244-A DCRT and line SN216 out of service was the preferred alternative for routing of cross-site transfers from compliance, life cycle cost, and operational perspectives.

4. Ref: Letter, J. K. McClusky, RL, to H. J. Hatch, FDH, "Decision Document for 244-A Double Contained Receiver Tank (DCRT) Utilization," 96-WSD-319, dated November 27. 1997.

Discussion: This letter directs implementation of HNF-SD-W314-AGA-006, and refines the guidance to include over pressure protection and a new diversion box in AN farm with lines going to Valve Pits AN-A and AN-B. 


\begin{tabular}{|c|c|c|c|}
\hline Section & Category & Description & Requirement \\
\hline $\begin{array}{l}\text { USSR } 2.2 .1 \\
\text { TWRS SE } 4.2 .1 \\
\text { W-314 SE } \\
4.2 .1 .3\end{array}$ & Piping & $\begin{array}{c}\text { Replace the following transfer piping: } \\
\text { - Line SN-2 13/200 } \\
\text { - Line SL-502 } \\
\text { - Line SL-504 }\end{array}$ & $\begin{array}{l}\text { Safety Not required for safety. } \\
\text { Compliance No compliance issues identified. } \\
\text { Privatization Supports AN and AP privatization requirements. } \\
\text { Conduct of Operation Allow transfer lines to operate at full } \\
\text { capacity and avoid premature line failure due to pipe erosion. } \\
\text { Support accelerated tank farms closure. }\end{array}$ \\
\hline \multicolumn{4}{|c|}{ Additional Information } \\
\hline $\begin{array}{l}\text { Ref: } \mathrm{V} \\
\text { Privati } \\
\text { accept: } \\
\text { design } \\
\text { require }\end{array}$ & \multicolumn{3}{|c|}{$\begin{array}{l}\text { Ref: WHC-SD-WM-TI-750, Rev. O, "Alternative Generation and Analysis for Phase I Privatization Transfer System Needs." Discussion: The preferred options for the } \\
\text { Privatization transfer system require the replacement and upgrade of } 2 \text { "SL-502 to } 3 \text {-inch, and replacement of } 3 \text { "SN-213/200. The upgrade of SL-502 is required to obtain } \\
\text { acceptable head requirements for transfers from the } 241 \text {-AY Farm to the Privatization tanks AP- } 106 \text { and } 108 \text {. The replacement of SN-213/200 is required to increase the } \\
\text { design pressure limit of the transfers from the } 241 \text {-AN and } 241 \text {-AZ Farms. The existing SN-213/200 has a design pressure limit of } 230 \text { psi, which is below the pressure } \\
\text { required to transfer waste from the } 241 \text { AN Farm to the } 241 \text {-AP Farm. and from the } 241 \text {-AZ Farm to the Privatization contractor's site. }\end{array}$} \\
\hline $\begin{array}{l}\text { Ref: S } \\
\text { Discus } \\
\text { SN-21 } \\
\text { Transf } \\
\text { affirma }\end{array}$ & \multicolumn{3}{|c|}{$\begin{array}{l}\text { Ref: SD-RE-TI-148, Rev. 0, "Metallurgical Analysis of Leak Failure of } 24 \text { l-A-B Valve Pit Jumper." } \\
\text { Discussion: The same transfer that caused the failure of the } 241-\mathrm{A}-\mathrm{A} \text { Valve Pit Jumper and line SN-233 is believed to have reduced the wall thickness on transfer lines } \\
\text { SN-213/200. SL-502, and SL-504. Transfer line SL-503 has already failed and is currently being replaced. Controlled on transfer lines SN-213/200, SL-502, and SL-504. } \\
\text { Transfer line SL-503 has already failed and is currently being replaced. Controlled photographs numbered } 8501893-6 \mathrm{CN}, 8503999-6 \mathrm{CN} \text {, and } 850399-4 \mathrm{CN} \text { provide visual } \\
\text { aftirmation of piping degradation due to corrosion along the route serviced by these lines. }\end{array}$} \\
\hline
\end{tabular}




\begin{tabular}{|c|c|c|c|}
\hline Section & Category & Description & Requirement \\
\hline $\begin{array}{l}\text { USSR } 2.2 .1 \\
\text { TWRS SE } 4.2 .1 \\
\text { W-314 SE } \\
4.2 .1 .3\end{array}$ & Piping & $\begin{array}{l}\text { Install a new diversion box in, or adjacent to, AN tank farm to } \\
\text { provide the East termination point of the cross-site transfer lines, } \\
\text { incorporate over-pressure protection for the cross-site, facilitate } \\
\text { installation of new lines to AN-A and AN-B valve pits, provide } \\
\text { rigid jumper to enable cross-site transfers to go directly to 103-AN, } \\
\text { and provide the ability to transfer waste cross-site from East Tank } \\
\text { Farms. }\end{array}$ & $\begin{array}{l}\text { Safety Not required for safety. } \\
\text { Compliance No compliance issues identified. } \\
\text { Privatization Supports AN and AP privatization requirements. } \\
\text { Conduct of Operation Add waste routing flexibility while reducing } \\
\text { personnel exposure to hazards associated with the 244-A DCRT. } \\
\text { Reduction of maintenance and operations activities. Support } \\
\text { accelerated tank farms closure }\end{array}$ \\
\hline
\end{tabular}

1. Ref: HNF-SD-W314-AGA-006. Rev 0, "Alternative Generation and Analysis Report for 244-A DCRT Utilization"

Discussion: This AGA reached the conclusion that relocating the termination point for the cross-site transfer line to AN Tank Farm and taking the 244-A DCRT and line SN216 out of service was the preferred alternative for routing of cross-site transfers from compliance, life cycle cost, and operational perspectives.

2. Ref: Letter, J. K. McClusky, RL, to H. J. Hatch, FDH, "Decision Document for 244-A Double Contained Receiver Tank (DCRT) Utilization," 96-WSD-319, dated November 27, 1997

Discussion: This letter directs implementation of HNF-SD-W314-AGA-006, and refines the guidance to include over pressure protection and a new diversion box in AN farm with lines going to Valve Pits AN-A and AN-B 
HNF - SD - W314-RPT- 003

Revision 2

\begin{tabular}{|c|c|c|c|}
\hline Section & Category & Description & Requirement \\
\hline $\begin{array}{l}\text { USSR 2.2.1 } \\
\text { TWRS SE 4.2.1 } \\
\text { W-314 SE } \\
4.2 .1 .3\end{array}$ & Piping & Permanently cap all waste transfer lines going to 244-A DCRT. & $\begin{array}{l}\text { Safety Not required for safety. } \\
\text { Compliance No compliance issues identified. } \\
\text { Privatization No privatization issues identified. } \\
\text { Conduct of Operation Provide safe condition for 244-A DCRT in } \\
\text { preparation for future de-activation }\end{array}$ \\
\hline \multicolumn{4}{|c|}{$\begin{array}{l}\text { Ref: HNF-SD-W314-AGA-006, Rev 0, "Alternative Generation and Analysis Report for 244-A DCRT Utilization" } \\
\text { Discussion: This AGA reached the conclusion that relocating the termination point for the cross-site transfer line to AN Tank Farm and taking the } 244-A \text { DCRT and line SN- } \\
216 \text { out of service was the preferred alternative for routing of cross-site transfers from compliance, life cycle cost, and operational perspectives. } \\
\text { Ref: Letter, J. K. McClusky, RL, to H. J. Hatch, FDH, "Decision Document for 244-A Double Contained Receiver Tank (DCRT) Utilization," } 96-\text { WSD-319, dated } \\
\text { November } 27,1997 \text {. } \\
\text { Discussion: This letter directs implementation of HNF-SD-W314-AGA-006, and retines the guidance to include over pressure protection and a new diversion box in AN } \\
\text { farm with lines going to Valve Pits AN-A and AN-B. }\end{array}$} \\
\hline
\end{tabular}




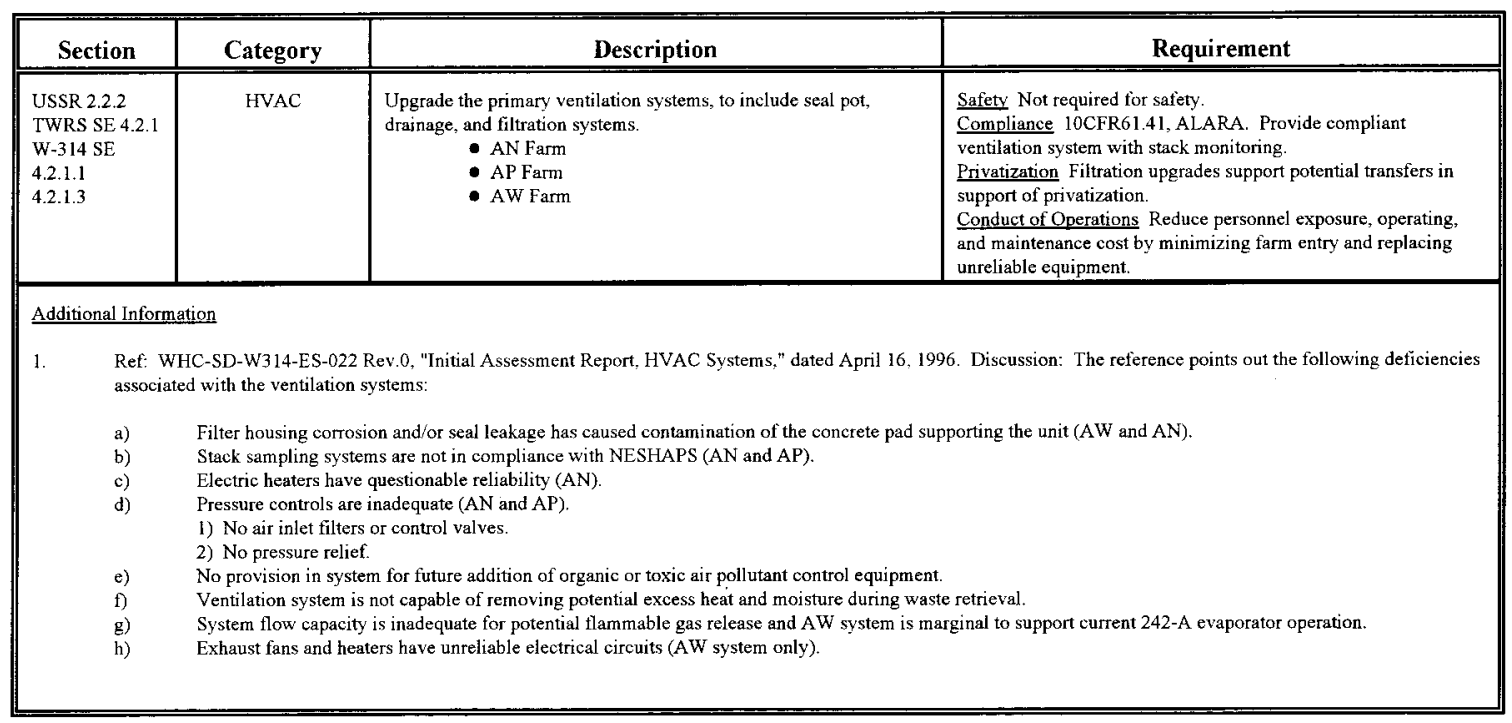


HNF - SD-W314-RPT-003

Revision 2

\begin{tabular}{|c|c|c|c|}
\hline Section & Category & Description & Requirement \\
\hline $\begin{array}{l}\text { USSR } 2.2 .2 \\
\text { TWRS SE } 4.2 .1 \\
\text { W-314 SE } \\
4.2 .1 .1 \\
4.2 .1 .3\end{array}$ & HVAC & $\begin{array}{l}\text { Upgrade the annulus ventilation system for } \mathrm{SY} \text { farm. The } \\
\text { ventilation system will include seal pot, drainage, and filtration } \\
\text { systems. }\end{array}$ & $\begin{array}{l}\text { Safety Not required for safety. } \\
\text { Compliance 10CFR61.41, ALARA. Provide organic compliant } \\
\text { ventilation system with stack monitoning. } \\
\text { Privatization No privatization requirements identified. } \\
\text { Conduct of Operations Reduce personnel exposure, operating, } \\
\text { and maintenance cost by minimizing farm entry and replacing } \\
\text { unreliable equipment. }\end{array}$ \\
\hline
\end{tabular}

Additional information

1. Ref: WHC-SD-W314-022 Rev. 0, "Project W-314 HVAC Systems, Initial Assessment," dated Aptil 16, 1996.

Discussion: Annulus exhaust filtration system is not in compliance with section 10.5 of ASME N510. Annulus inlet HEPA filters do not comply with ASME N509 and are difficult to aerosol test. Annulus exhaust steam heating coil is not in service and is not in compliance with ASME N509. The annulus ventilation system exhaust fan reliability is questionable.

2. Discussion: The present yentilation system was installed in 1976, and is approaching the end of it's useful life. The system is difficult to maintain and there is corrosion evident in the system's plenums. The $241-\mathrm{SY}$ Tank Farm will support all the transfers from the 200 West area to the 200 East area. Since $24 \mathrm{l}-\mathrm{SY}$ will receive all wastes to be transferred, the ventilation system must be in proper working condition and should be flexible enough to address any situation that could be created by the different wastes (e.g. flammable gas, organics, etc.) coming to the tank farm. 


\begin{tabular}{|c|c|c|c|}
\hline Section & Category & Description & Requirement \\
\hline $\begin{array}{l}\text { USSR } 2.2 .2 \\
\text { TWRS SE } 4.2 .1 \\
\text { W-314 SE } \\
4.2 .1 .1 \\
4.2 .1 .3\end{array}$ & HVAC & $\begin{array}{l}\text { Upgrade the ventilation systems for 244-S DCRT. The ventilation } \\
\text { system will include seal pot, drainage, and filtration systems. }\end{array}$ & $\begin{array}{l}\text { Safety Not required for safety. } \\
\text { Compliance 10CFR61.41, ALARA. Provide compliant } \\
\text { ventilation system with stack monitoring. } \\
\text { Privatization No privatization requirements identified. } \\
\text { Conduct of Operations Reduce personnel exposure, operating, } \\
\text { and maintenance costs by minimizing farm entry and replacing } \\
\text { unreliable equipment. }\end{array}$ \\
\hline \multicolumn{4}{|c|}{ Additional Information } \\
\hline $\begin{array}{l}\text { Ref } \\
\text { Dis } \\
\text { a) } \\
\text { b) } \\
\text { c) } \\
\text { d) } \\
\text { c) } \\
\text { f) } \\
\text { g) } \\
\text { h) }\end{array}$ & $\begin{array}{l}\text { IC-SD-W314-ES- } \\
\text { The reference } \\
\text { The existing HEI } \\
\text { Exhaust fans and } \\
\text { Pressure controls } \\
\text { Location of venti } \\
\text { No provisions in } \\
\text { Ventilation syste } \\
\text { System flow cape } \\
\text { The DCRT is req }\end{array}$ & $\begin{array}{l}\text { ev, 0, "initial Assessment Report. HVAC Systems," dated April 16, } \\
\text { sout the following iterns: } \\
\text { ter systems do not meet aerosol uniformity test criteria. } \\
\text { ric heaters have questionable reliability. } \\
\text { nadequate because there are no inlet filters or control valves and no p } \\
\text { equipment in pit makes maintenance difficult and hazardous. } \\
\text { ms for future addition of organic or toxic air pollutant control equipm } \\
\text { e not capable of removing potential excess heat and moisture during } \\
\text { is inadequate for potential flammable gas release. } \\
\text { to support DST waste transfer operations. }\end{array}$ & $\begin{array}{l}\text { sure relief. } \\
\text { t. } \\
\text { ieval. }\end{array}$ \\
\hline
\end{tabular}




\begin{tabular}{||c|l|l|l|}
\hline Section & Category & \multicolumn{1}{|c|}{ Description } & \multicolumn{1}{c|}{ Requirement } \\
\hline \hline USSR 2.2.3 & Instrumentation & Replace the existing method of annulus leak detection in DSTs & Safety Not required for safety. \\
TWRS SE 4.2.1 & and Control & with better technology. & $\begin{array}{l}\text { Compliance 40CFR265.193, detection of leaks to secondary } \\
\text { W-314 SE }\end{array}$ \\
4.2 .1 .1 & & & $\begin{array}{l}\text { Containment within 24 hours. } \\
\text { Privatization No privatization requirements identified. }\end{array}$ \\
& & & $\begin{array}{l}\text { Conduct of Operations Reduce personnel exposure, operating, } \\
\text { and maintenance costs by minimizing farm entry for data } \\
\text { collection and eliminating unreliable instruments. }\end{array}$ \\
\hline
\end{tabular}

Additional Information

1. Ref: WHC-SD-W314-ES-018 Rev, 0, "Project W-314 DST and DCRT Instrument and Control Systems, Initial Assessment," dated November 17, 1995. Discussion: the flake box housings for the manual tapes are deteriorated. The housings are constructed of plastic which has been affected by sunlight and has o-ring seals which require frequent replacement. The o-ring replacement requires work inside the housing which is installed on a tank riser. The wiring for the 'multi-point conductivity' probes is direct buried cable which is degrading.

2. Ref: WHC-SD-W314-ER-002, Rev. 0, "241-AW Tank Farm Upgrades," dated August 1995.

Discussion: The 'manual tape' method is not fully compatible with 40CFR265 and WAC-173-303, and neither the 'manual tape' or the 'multi-point conductivity' methods can detect small leaks or detect leaks in a timely manner. Additionally, the 'manual tape' is manually operated as to positioning as close to the annulus floor as possible. This positioning make the measurement subject to operator interpretation, which causes repeatability errors. The remaining expected life of the 'manual tapes' is 5-10 years.

3. Discussion: The 'manual tape' housing is purged with instrument air. Minimizing or eliminating the use of instrument air reduces maintenance requirements. Additionally, the frequency with which the 'manual tape' leak detectors are monitored suggests a need for automatic monitoring and recording and use of the 'manual tape' leak detectors requires an operator to enter the farm which increases operator exposure. 


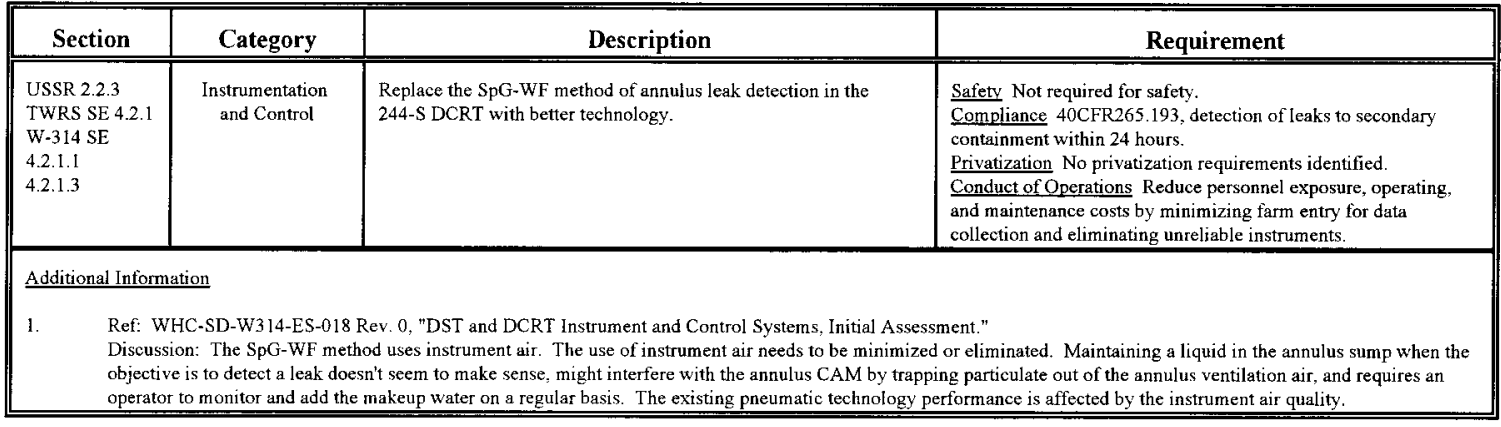




\begin{tabular}{|c|c|c|c|}
\hline Section & Category & Description & Requirement \\
\hline $\begin{array}{l}\text { USSR } 2.2 .3 \\
\text { TWRS SE } 4.2 .1 \\
\text { W-314 SE } \\
4.2 .1 .1 \\
4.2 .1 .3\end{array}$ & $\begin{array}{l}\text { Instrumentation } \\
\text { and Control }\end{array}$ & $\begin{array}{l}\text { Upgrade the CAM annulus leak detectors in DST's and DCRT with } \\
\text { new models. }\end{array}$ & $\begin{array}{l}\text { Safety Not required for safety. } \\
\text { Compliance } 40 \text { CFR } 265.193 \text {, detection of leaks to secondary } \\
\text { containment within } 24 \text { hours. } \\
\text { Privatization No privatization requirements identified. } \\
\text { Conduct of Operations Reduce personnel exposure, operating, } \\
\text { and maintenance costs by minimizing farm entry for data } \\
\text { collection and eliminating unreliable instruments. }\end{array}$ \\
\hline
\end{tabular}

Additional Information

1. Ref: WHC-SD-W314-ES-018 Rev. 0, "Project W-314 DST and DCRT Instrument and Control Systems, Initial Assessment," dated November 17, 1995.

Discussion: The existing CAM's are too sensitive to radon gas which results in false alarms. The maintenance and calibration is difficult because the weight of the unit is greater than $100 \mathrm{lbs}$., and the CAM is hard to access, and I typically hard bolted into a weather cabinet. The three (3) open chart recorders used to record the CAM signal are in continual need of repair. The new Hanford Standard CAM is the AMS.4 which is replacing these AMS-3 site wide. The CAM signal wiring is direct buried in all farms except AP and in some cases the wire is already 25 years old and deteriorating.

2. Discussion: The DCRT leak detection system is not reliable, is not protected from the environment, and is not a good design for monitoring the annulus air for radioactive particulate.

1. Ref: WHC-SD-W314-ES-018 Rev. 0, "DST and DCRT Instrument and Control Systems, Initial Assessment."

Discussion: The SpG-WF method uses instrument air. The use of instrument air needs to be minimized or eliminated. Maintaining a liquid in the annulus sump when the objective is to detect a leak doesntt seem to make sense, might interfere with the annulus CAM by trapping particulate out of the annulus ventilation air, and requires an operator to monitor and add the makeup water on a regular basis. The existing pneumatic technology performance is affected by the instrument air quality. 


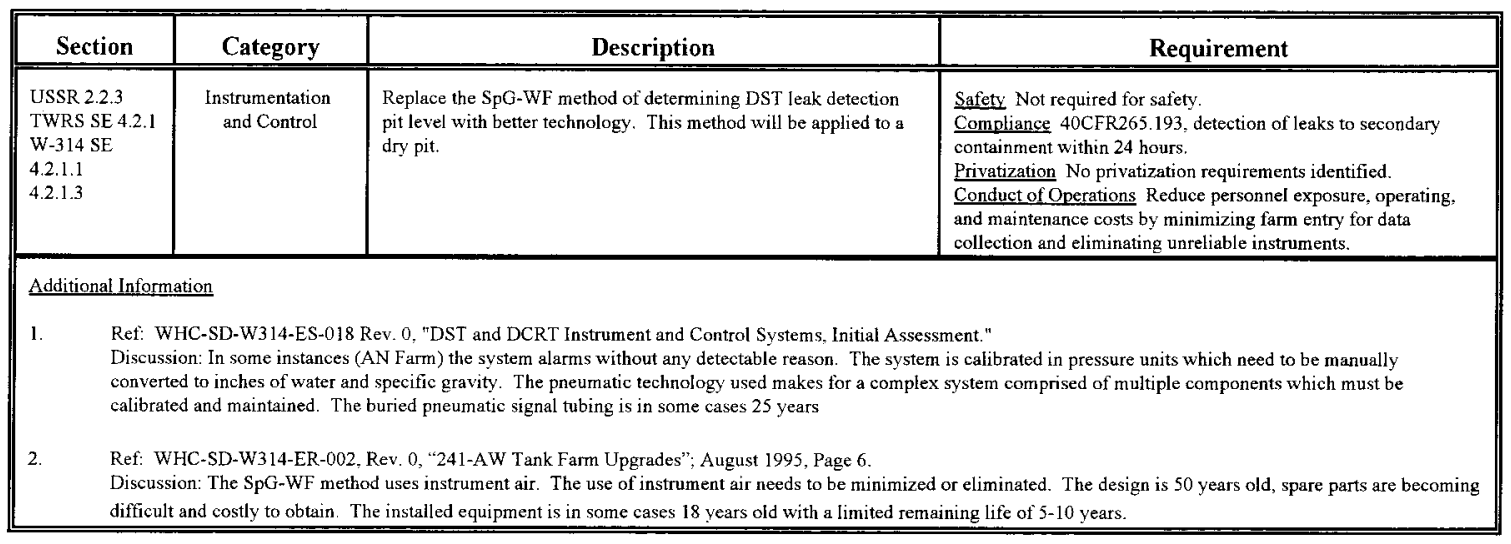


HNF - SD-W314-RPT- 003

Revision 2

\begin{tabular}{|c|c|c|c|}
\hline Section & Category & Description & Requirement \\
\hline $\begin{array}{l}\text { USSR } 2.2 .3 \\
\text { TWRS SE } 4.2 .1 \\
\text { W-314 SE } \\
4.2 .1 .1 \\
4.2 .1 .3\end{array}$ & $\begin{array}{l}\text { Instrumentation } \\
\text { and Control }\end{array}$ & Alarm DST leak detection pit high liquid level. & $\begin{array}{l}\text { Safety Not required for safety. } \\
\text { Compliance No compliance issues identified. } \\
\text { Privatization No privatization requirements identified. } \\
\text { Conduct of Operations Provide an engineered barrier to eliminate } \\
\text { pressurizing the bottom of the DST. }\end{array}$ \\
\hline \multicolumn{4}{|c|}{ Additional Information } \\
\hline $\begin{array}{l}\text { Discus } \\
\text { that the }\end{array}$ & \multicolumn{3}{|c|}{$\begin{array}{l}\text { Discussion: A high leak detection pit level alarm provides a warning that the secondary tank may be over stressed by a high hydraulic head in the leak detection pit. (Note } \\
\text { that the outside wall of the secondary containment is connected to the leak detection pit by open drain pipes from under the tank. }\end{array}$} \\
\hline
\end{tabular}


HNF-SD-W314-RPT- 003

Revision 2

\begin{tabular}{|c|c|c|c|}
\hline Section & Category & Description & Requirement \\
\hline $\begin{array}{l}\text { USSR } 2.2 .3 \\
\text { TWRS SE 4.2. } \\
\text { W-314 SE } \\
4.2 .1 .1 \\
4.2 .1 .3\end{array}$ & $\begin{array}{l}\text { Instrumentation } \\
\text { and Control }\end{array}$ & Alarm high liquid level in DSTs & $\begin{array}{l}\text { Safety Not required for safety. } \\
\text { Compliance } 40 \text { CFR } 265.193 \text {, appropriate controls required to } \\
\text { eliminate tank overfill. } \\
\text { Privatization No privatization requirements identified. } \\
\text { Conduct of Operations Provide an engineered barier to eliminate } \\
\text { operating errors which could result in tank overfill and spillage of } \\
\text { waste. }\end{array}$ \\
\hline \multicolumn{4}{|c|}{ Additional Information } \\
\hline $\begin{array}{l}\text { Discus } \\
\text { operati } \\
\text { The sy }\end{array}$ & \multicolumn{3}{|c|}{$\begin{array}{l}\text { Discussion: The existing system is not intrinsically safe (sealed and spark free) which makes it unsuitable for use in a hazardous atmosphere. The existing system is not } \\
\text { operationally testable and it is required to have this capability for systems that have a contact exposure greater than } 50 \text { mrem/hr. The signal wire is a direct buried cable. } \\
\text { The system uses current sensitive relays which cannot be calibrated to the sensor. }\end{array}$} \\
\hline
\end{tabular}


HNF - SD-W3 14-RPT-003

Revision 2

\begin{tabular}{|c|c|c|c|}
\hline Section & Category & Description & Requirement \\
\hline $\begin{array}{l}\text { USSR } 2.2 .3 \\
\text { TWRS SE } 4.2 .1 \\
\text { W-314 SE } \\
4.2 .1 .1 \\
\text { 4.2.1.3 }\end{array}$ & $\begin{array}{l}\text { Instrumentation } \\
\text { and Control }\end{array}$ & $\begin{array}{l}\text { Replace existing clean out box leak detectors systems with an } \\
\text { operationally testable system. }\end{array}$ & $\begin{array}{l}\text { Safety Not required for safety, } \\
\text { Compliance } 40 \text { CFR } 265.193 \text {, detection of leaks to secondary } \\
\text { containment within } 24 \text { hours. } \\
\text { Privatization No privatization requirements identified. } \\
\text { Conduct of Operations Reduce personnel exposure, operating, } \\
\text { and maintenance costs by improving control of waste transfers } \\
\text { and eliminating shutdowns due to false alarms. }\end{array}$ \\
\hline \multicolumn{4}{|c|}{$\begin{array}{l}\text { 1. Ref: WHC-SD-W314-ES-018 Rev. 0, "Project W-314 DST and DCRT Instrument and Control Systems, Initial Assessment," dated November 17, } 1995 . \\
\text { Discussion: Clean out boxes used direct buried "SO" cord, which is degrading and is in violation of the NEC. }\end{array}$} \\
\hline 2. & er & own discussion below for leak detectors in general. & \\
\hline
\end{tabular}




\begin{tabular}{|c|c|c|c|}
\hline Section & Category & Description & Requirement \\
\hline $\begin{array}{l}\text { USSR } 2.2 .3 \\
\text { TWRS SE } 4.2 .1 \\
\text { W-314 SE } 4.2 .1 .1 \\
4.2 .1 .3\end{array}$ & $\begin{array}{l}\text { Instrumentation } \\
\text { and Control }\end{array}$ & $\begin{array}{l}\text { Replace existing transfer system leak detectors with an operationally } \\
\text { testable system in: } \\
\text { - DST Farms (all valve/pump pits, diversion boxes, etc) } \\
\text { - DCRT Transfer Pits } \\
\text { - Pipeline Encasements }\end{array}$ & $\begin{array}{l}\text { Safety Not required for safety. } \\
\text { Compliance } 40 \text { CFR } 265.193 \text {, detection of leaks to secondary } \\
\text { containment within } 24 \text { hours. } \\
\text { Privatization No privatization requirements identified. } \\
\text { Conduct of Operations Reduce personnel exposure, operating, and } \\
\text { maintenance costs by improving control of waste transfers and } \\
\text { eliminating shutdowns due to false alarms. }\end{array}$ \\
\hline \multicolumn{4}{|c|}{ Additional Information } \\
\hline \multicolumn{4}{|c|}{$\begin{array}{l}\text { 1. Ref: WHC-SD-W314-ES-018 Rev, 0, "Project W-314 DST and DCRT Instrument and Control Systems, Initial Assessment:" dated November 17, } 1995 . \\
\text { Discussion: Clean out boxes used direct buried "SO" cord, which is degrading and is in violation of the NEC. }\end{array}$} \\
\hline
\end{tabular}


HNF - SD-W314-RPT-003

Revision 2

\begin{tabular}{|c|c|c|c|}
\hline Section & Category & Description & Requirement \\
\hline $\begin{array}{l}\text { USSR } 2.2 .3 \\
\text { TWRS SE } 4.2 .1 \\
\text { W-314 SE } \\
4.2 .1 .1 \\
4.2 .1 .3\end{array}$ & $\begin{array}{l}\text { Instrumentation } \\
\text { and Control }\end{array}$ & $\begin{array}{l}\text { Verify waste transfer routing as required on routing between the } \\
\text { DST farms and the DCRT through the use of: } \\
\text { - Valve position indication } \\
\text { - Flow monitoring }\end{array}$ & $\begin{array}{l}\text { Safety Not required for safety. } \\
\text { Compliance } 40 \text { CFR } 265.193 \text {, eliminate spills due to mis-routing. } \\
\text { Privatization Supports AN and AP privatization requirements. } \\
\text { Conduct of Operations Reduce personnel exposure and cleanup } \\
\text { costs by assuring transfers are executed as planned. }\end{array}$ \\
\hline
\end{tabular}

Additional Information

1. Discussion: Adequate "status of the route isolation" using pipeline pressure is not presently provided for all transfer routes. Transfer route identification cannot be verified without entering a tank farm. Remote route verification reduces operator entries into the tank farms resulting in operations cost savings and compliance with ALARA

principles by reducing the radiation exposure. In later years when waste transfers increase, remote verifications will make high volume waste transfers more manageable. Existing valve position limit switches are problematic. Route verification assists compliance with DOE $5280.2 \mathrm{~A} .13 . \mathrm{B}$, which requires control and maintaining chemical composition of the DSTs. Unknown quantities of mis-routed waste being added to the DSTs, makes compliance with DOE 5280.2A.13.b very difficult, if not impossible. Reestablishing the waste compositions is expensive since a sample from each DST that received waste will need to be extracted and analyzed. Quick route verification minimizes this problem if, immediately upon detecting a mis-routing, the waste transfer is shutdown, and the mis-routing is corrected. 


\begin{tabular}{|c|c|c|c|}
\hline Section & Category & Description & Requirement \\
\hline $\begin{array}{l}\text { USSR } 2.2 .3 \\
\text { TWRS SE } 4.2 .1 \\
\text { W-314 SE } \\
4.2 .1 .1 \\
4.2 .1 .3\end{array}$ & $\begin{array}{l}\text { Instrumentation } \\
\text { and Control }\end{array}$ & $\begin{array}{l}\text { Upgrade the master pump shutdown system to use operationally } \\
\text { testable components, and to replace the relay based approach in the } \\
\text { DST farms, 242-A Evaporator, and SST farms as specified. }\end{array}$ & $\begin{array}{l}\text { Safety Not required for safety. } \\
\text { Compliance } 40 \text { CFR } 265.193 \text {, detection of leaks and shutdown of } \\
\text { transfer. } \\
\text { Privatization No privatization requirements identified. } \\
\text { Conduct of Operations Reduce personnel exposure, operating, } \\
\text { and maintenance costs by improving control of waste transfers } \\
\text { and eliminating shutdowns due to false alarms. }\end{array}$ \\
\hline
\end{tabular}

Additional Information

1. Ref: WHC-SD-W3 14-ES-018 Rev. 0; "DST and DCRT Instrument and Control Systems, Initial Assessment," dated

November 17, 1995

Discussions: The hardwired MPS system requires an engineering change notice and field hardware modifications to add or delete a sensor. The MPS push-button control panels in the 242-A, 242-S. and the 271-A do not appear to be in accordance with NUREG 7000. Signal wiring in the tank farms to the 242-A MPS control panel is direct buried, not maintainable, and is reaching the end of its design life

2. Ref: WHC-SD-W314-ER-002, Rev. 0; 241-AW Tank Farm Upgrades; August 1995

Discussions: Individual leak detectors cannot be readily or remotely identified resulting in time consuming tank farm field walkdowns to determine the cause of the alarm. Greater versatility and reliability will be required in the future when the number of waste transfers increase.

3. Discussion: Any leak detector, even if it is not associated with the current active transfer route, will shut down all transfers. This increases the number of spurious waste transfer shutdowns which severely degrades the Waste Transfer System reliability.

GENERAL LEAK DETECTOR DISCUSSION FOR CLEAN OUT BOX, PIT, AND PIPELINE SECTIONS.

4 Ref: WHC-SD-W314-ES-018 Rev. 0; "DST and DCRT Instrument and Control Systems, Initial Assessment," dated November 17, 1995.

Discussion: The current sensitive relays fail. Leak detectors in the pits are not secured in place allowing them to be moved from the low point or knocked over. The field electronics stations have terminal box enclosures with indicator lights installed in such a way that the weatherproof rating of the enclosure is nullified.

5. Discussion: Pit leak detectors cannot detect small leaks due to the detector installation one inch off the pit floor. The leak detector signal wiring is badly deteriorated and does not comply with NEC. Leak detector electrical boxes are no longer capable of NEMA rating due to improper modification and mainteriance. Leak detector calibration is not possible. Pit leak detectors are subject to false alarms caused by rain and melting snow infiltration. The pump pit leak detector could be subjected to a flammable atmosphere and needs to be of an intrinsically sate design.

6. Ref: WHC-SD-W314-ER-002, Rev. 0:241-AW Tank Farm Upgrades; August 1995.

Discussion: The pit leak detectors are not fully compliant with 40CFR265 and WAC-173-303. Leak detection non-commercial design makes part replacement difficult and costly 
HNF - SD-W3 14 - RPT - 003

Revision 2

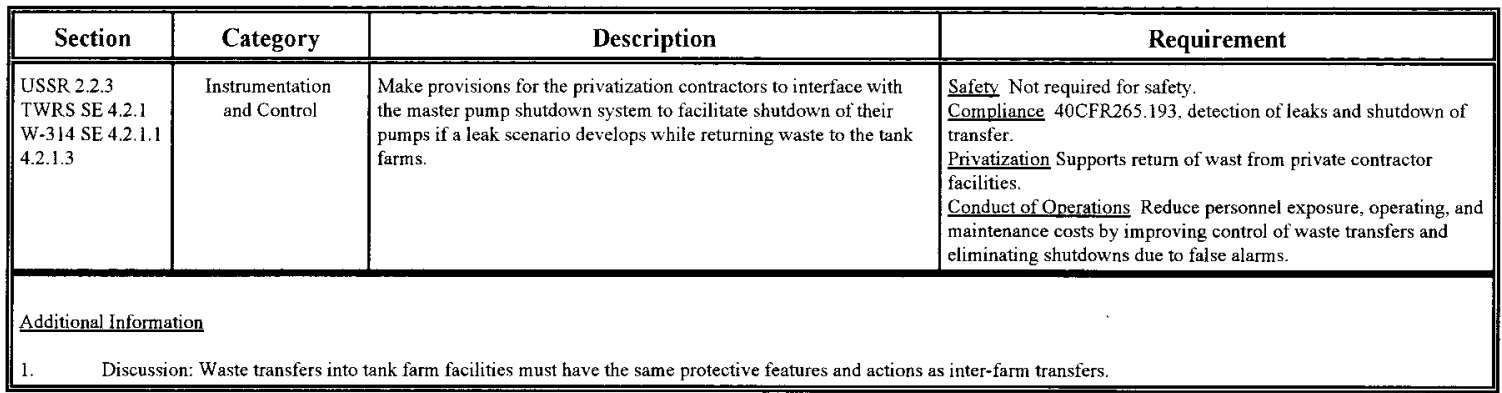


HNF - SD-W314-RPT-003

Revision 2

\begin{tabular}{|c|c|c|c|}
\hline Section & Category & Description & Requirement \\
\hline $\begin{array}{l}\text { USSR } 2.2 .3 \\
\text { TWRS SE } 4.2 .1 \\
\text { W.314 SE } \\
4.2 .1 .1 \\
4.2 .1 .3\end{array}$ & $\begin{array}{l}\text { Instrumentation } \\
\text { and Control }\end{array}$ & $\begin{array}{l}\text { Upgrade the master pump shutdown relay panel in the } 242-A \text {, and } \\
\text { upgrade and move the panel out of the } 242-S \text { Evaporators. }\end{array}$ & $\begin{array}{l}\text { Safety Not required for safety. } \\
\text { Compliance } 40 \text { CFR265.193, detection of leaks and shutdown of } \\
\text { transfer. } \\
\text { Privatization No privatization requirements identified. } \\
\text { Conduct of Operations Reduce personnel exposure and cleanup } \\
\text { costs by improving control of waste transfers and eliminating } \\
\text { shutdowns due to false alarms. }\end{array}$ \\
\hline \multicolumn{4}{|c|}{ Additional Information } \\
\hline $\begin{array}{l}\text { Discus } \\
\text { demoli }\end{array}$ & \multicolumn{3}{|c|}{$\begin{array}{l}\text { Discussion: The existing panels do nol allow interlock versatility resulting in inappropriate shutdowns. The } 242-S \text { functions need to be moved in anticipation of the } 242-S \\
\text { demolition. }\end{array}$} \\
\hline
\end{tabular}


HNF-SD-W314-RPT-003

Revision 2

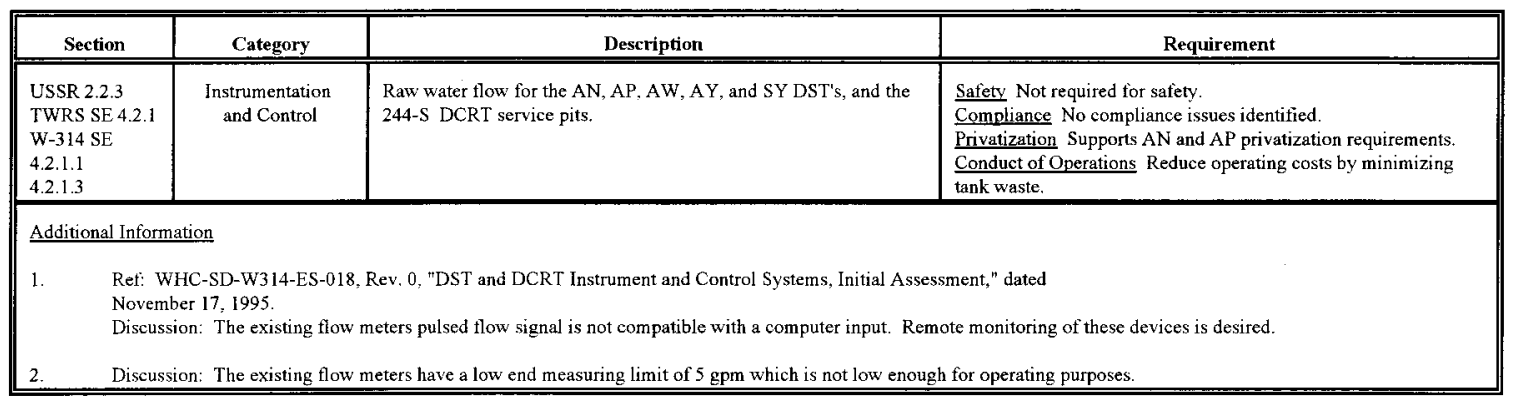


HNF - SD - W3 14-RPT-003

Revision 2

\begin{tabular}{|c|c|c|c|}
\hline Section & Category & Description & Requirement \\
\hline $\begin{array}{l}\text { USSR } 2.2 .3 \\
\text { TWRS SE } 4.2 .1 \\
\text { W-314 SE } \\
4.2 .1 .1 \\
4.2 .1 .3\end{array}$ & $\begin{array}{l}\text { Instrumentation } \\
\text { and Control }\end{array}$ & $\begin{array}{l}\text { Raw water radiation (backflow detection) at the } 244-S \text { DCRT } \\
\text { service pit. }\end{array}$ & $\begin{array}{l}\text { Safety Not required for safety. } \\
\text { Compliance } 40 \text { CFR } 265.193 \text {, detection of leaks to secondary } \\
\text { containment within } 24 \text { hours. } \\
\text { Privatization No privatization requirements identified. } \\
\text { Conduct of Operations Reduce operating costs by minimizing } \\
\text { tank waste. }\end{array}$ \\
\hline \multicolumn{4}{|c|}{$\begin{array}{l}\text { Ref: WHC-SD-W3 14-ES-018, Rev. 0, "DST and DCRT Instrument and Control Systems, Initial Ass } \\
\text { November 17, } 1995 \text {. } \\
\text { Discussion: This is a unique Hanford designed item which makes obtaining spare parts a problem. }\end{array}$} \\
\hline \multicolumn{4}{|c|}{ Discussion: The system is not reliable and the equipment is not protected from environment. The design is not optimum for detecting radiation in the pipe. } \\
\hline
\end{tabular}


HNF - SD - W314-RPT-003

Revision 2

\begin{tabular}{|c|c|c|c|}
\hline Section & Category & Description & Requirement \\
\hline $\begin{array}{l}\text { USSR } 2.2 .3 \\
\text { TWRS SE } 4.2 .1 \\
\text { W-314 SE } \\
4.2 .1 .1 \\
4.2 .1 .3\end{array}$ & $\begin{array}{l}\text { Instrumentation } \\
\text { and Control }\end{array}$ & Provide leak detection of new piping. & $\begin{array}{l}\text { Safety Not required for safety. } \\
\text { Compliance 40CFR265.193, detection of leaks to secondary } \\
\text { containment within } 24 \text { hours. } \\
\text { Privatization Supports AN and AP privatization requirements. } \\
\text { Conduct of Operations Reduce personnel exposure and operating } \\
\text { costs by improving control of waste transfers and eliminating } \\
\text { shutdowns due to false alarms. }\end{array}$ \\
\hline Additional Info & & & \\
\hline
\end{tabular}




\begin{tabular}{|c|c|c|c|}
\hline Section & Category & Description & Requirement \\
\hline $\begin{array}{l}\text { USSR } 2.2 .3 \\
\text { TWRS SE } 4.2 .1 \\
\text { W-314 SE } \\
4.2 .1 .1 \\
4.2 .1 .3\end{array}$ & $\begin{array}{l}\text { Instrumentation } \\
\text { and Control }\end{array}$ & $\begin{array}{l}\text { Tank waste temperature, and liquid level in the DST's and the } \\
\text { DCRT. }\end{array}$ & $\begin{array}{l}\text { Safety Not required for safety. } \\
\text { Compliance DOE } 5820.2 \mathrm{~A} \text {, monitoring system requirements. } \\
\text { Privatization No privatization requirements identified. } \\
\text { Conduct of Operations Appropriate tank parameters are } \\
\text { monitored to assure conduct of operations and adherence to OSR } \\
\text { and other operating procedures. }\end{array}$ \\
\hline \multicolumn{4}{|c|}{ Additional Information } \\
\hline $\begin{array}{l}\text { TEMPERATUR } \\
\text { 1. Discu } \\
\text { all exi }\end{array}$ & \multicolumn{3}{|c|}{$\begin{array}{l}\text { Discussion: The individual elements need to be field replaceable to preclude operating without data or having to pull and replace the entire temperature tree assembly. Not } \\
\text { all existing temperature tree designs can withstand mixer pump forces. }\end{array}$} \\
\hline 1. Ref: & $\begin{array}{l}\text {-SD-W3 14-ES-0 } \\
17,1995 . \\
\text { Existing 'manus } \\
\text { aftactured making } \\
\text { ed to the existing }\end{array}$ & $\begin{array}{l}\text { Lev. 0; "DST and DCRT Instrument and Control Systems, Initial } \\
\text { dL- } 8839 \text {. The tank riser provides no means to isolate the device } \\
\text { re parts or replacement in kind difficult. The 'manual' type uses } \\
\text { S, the interface is obsolete and being replace by TMACS. }\end{array}$ & $\begin{array}{l}\text { ment," dated } \\
\text { commended for replacement with the Enraf-Nonius Model } 854 \text { by } \\
\text { e tank vapor space. The 'manual tape' gage is obsolete and no } \\
\text { uried signal cable which is deteriorating. The 'manual' tape signal }\end{array}$ \\
\hline $\begin{array}{l}\text { Discu } \\
\text { resolu } \\
\text { line. } \\
\text { dip tul }\end{array}$ & $\begin{array}{l}\text { It is desired that } \\
\text { making them subj } \\
\text { existing Enraf-Nor } \\
\text { wich are subject t }\end{array}$ & $\begin{array}{l}\text { level device have the capability to satisfy mass balance and tan } \\
\text { o operator interpretation resulting in poor repeatability of meast } \\
\text { gauges that have been installed need to be modified to allow co } \\
\text { ugging. }\end{array}$ & $\begin{array}{l}\text { ory requirements. The existing 'manual tape' gauges have poor } \\
\text {, and require extensive maintenance inside the tank farm fence } \\
\text { f the fuil tank range. The DCRT level measurement system uses }\end{array}$ \\
\hline
\end{tabular}




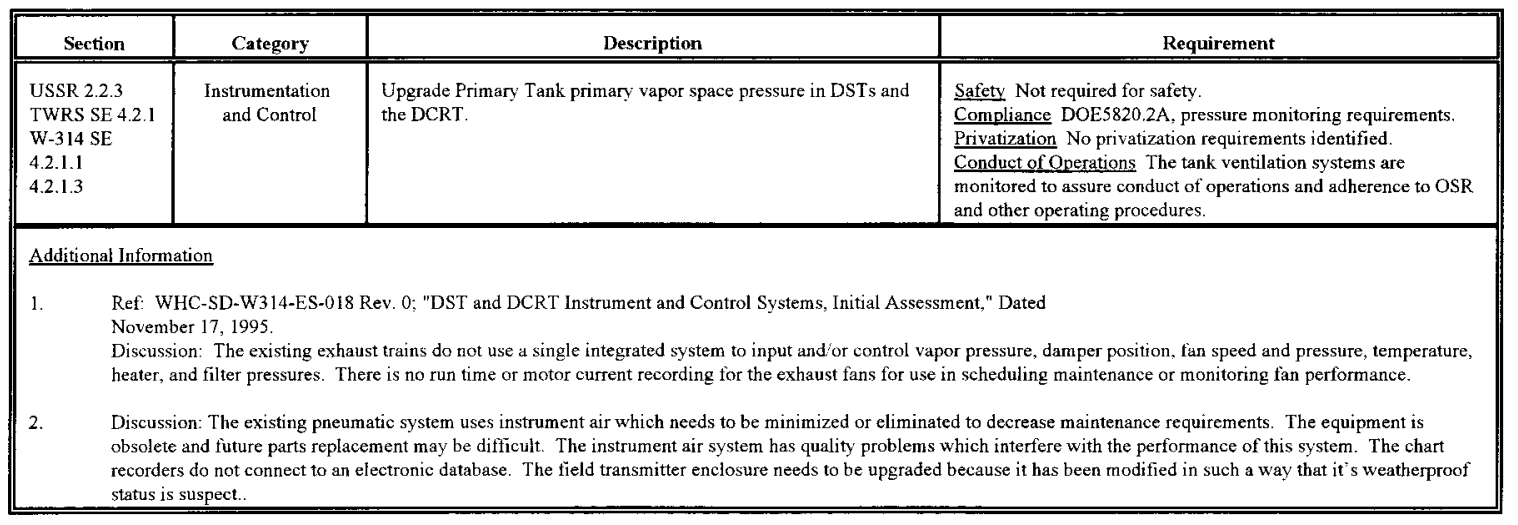




\begin{tabular}{|c|c|c|c|}
\hline Section & Category & Description & Requirement \\
\hline $\begin{array}{l}\text { USSR } 2.2 .3 \\
\text { TWRS SE } 4.2 .1 \\
\text { W-314 SE } \\
4.2 .1 .1 \\
4.2 .1 .3\end{array}$ & $\begin{array}{l}\text { Instrumentation } \\
\text { and Control }\end{array}$ & $\begin{array}{l}\text { Primary ventilation train pre-filter and HEPA filter differential } \\
\text { pressures, exhaust temperature, and exhaust heater differential } \\
\text { pressure for the } 244 \text {-S DCRT, and all DST farms except AY and } \\
\text { AZ. }\end{array}$ & $\begin{array}{l}\text { Safety Not required for safety. } \\
\text { Compliance DOE } 5820.2 \mathrm{~A} \text {, pressure monitoring requirements. } \\
\text { Privatization No privatization requirements identified. } \\
\text { Conduct of Operations The tank ventilation systems are } \\
\text { monitored to assure conduct of operations and adherence to OSR } \\
\text { and other operating procedures. }\end{array}$ \\
\hline
\end{tabular}

\section{Additional Information}

1. Ref: WHC-SD-W314-ES-018 Rev, 0; "DST and DCRT Instrument and Control Systems, Initial Assessment," Dated

November 17, 1995 .

Discussion: The existing exhaust trains do not use a single integrated system to input and/or control vapor pressure, damper position, fan speed and pressure, temperature, heater, and filter pressures. There is no run time or motor current recording for the exhaust fans for use in scheduling maintenance or monitoring fan performance.

2. Discussion: It is desired to have the system connected to remote monitoring so operators do not have to enter the tank farm to gather exhaust train status data. The heater controls require extensive maintenance, cannot be calibrated, and the heater thermostats have high failure rates. The AP tank farm heater control enclosures have been modified so extensively that they are no longer weatherproof. 


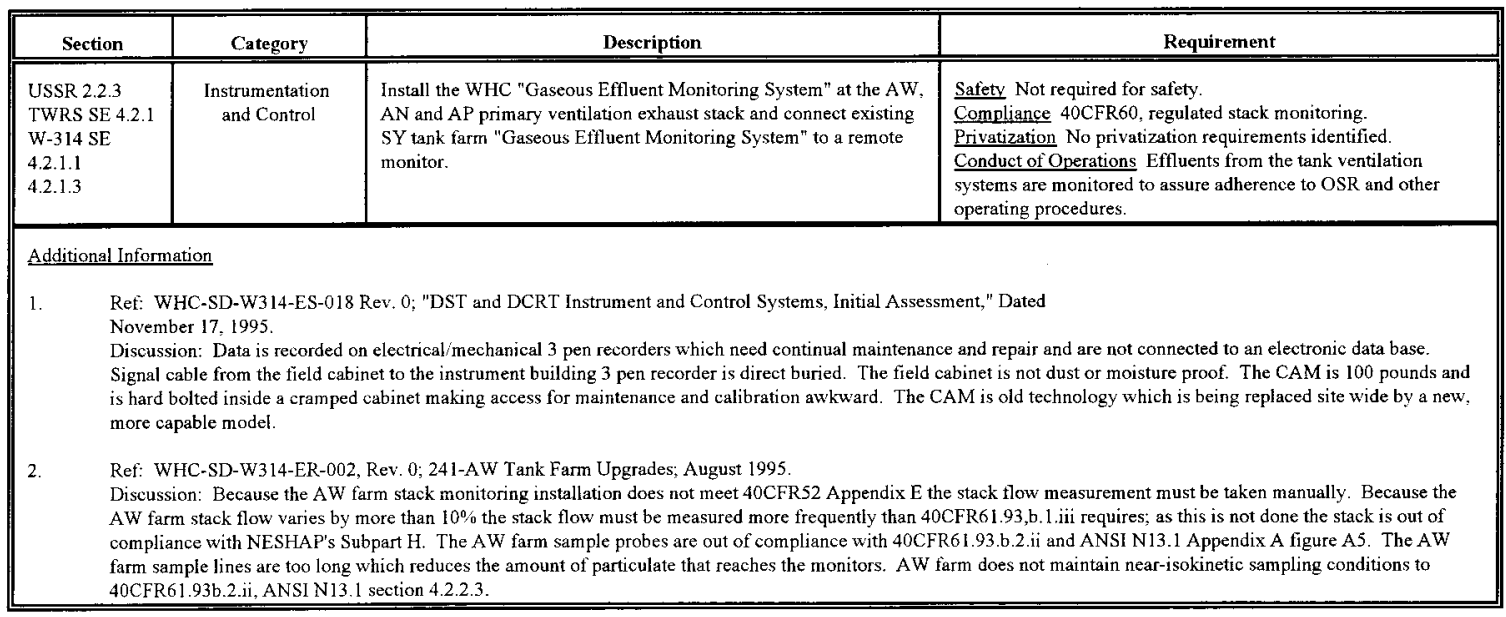


HNE - SD-W314-RPT-003

Revision 2

\begin{tabular}{|c|c|c|c|}
\hline Section & Category & Description & Requirement \\
\hline $\begin{array}{l}\text { USSR } 2.2 .3 \\
\text { TWRS SE } 4.2 .1 \\
\text { W-314 SE } \\
4.2 .1 .1 \\
4.2 .1 .3\end{array}$ & $\begin{array}{l}\text { Instrumentation } \\
\text { and Control }\end{array}$ & $\begin{array}{l}\text { Input DST farm annunciated signals ("Panalarm") into a } \\
\text { centralized monitoring system.. }\end{array}$ & $\begin{array}{l}\text { Safety Not required for safety. } \\
\text { Compliance DOE } 5820.2 \mathrm{~A} \text {, alarm and monitoring system } \\
\text { requirements. } \\
\text { Privatization No privatization requirements identified. } \\
\text { Conduct of Operations Appropriate alarms are assigned to } \\
\text { selected tank parameters to assure adherence to OSR and other } \\
\text { operating procedures as specified by conduct of operation. }\end{array}$ \\
\hline \multicolumn{4}{|c|}{ Additional Information } \\
\hline $\begin{array}{l}\text { Discus } \\
\text { on the }\end{array}$ & \multicolumn{3}{|c|}{$\begin{array}{l}\text { Discussion: The existing alarm panels do not appear to comply with NUREG-0700 for alarm identification. Not all the tank farm systems and instruments are monitored } \\
\text { on the existing alarm panels. Selected tank farm instrumentation should be monitored at a central location. }\end{array}$} \\
\hline
\end{tabular}


HNF-SD - W314-RPT- 003

Revision 2

\begin{tabular}{|c|c|c|c|c|}
\hline & & Category & Description & Requirement \\
\hline & $\begin{array}{l}2.3 \\
\text { E }\end{array}$ & $\begin{array}{l}\text { Instrumentation } \\
\text { and Control }\end{array}$ & $\begin{array}{l}\text { Replace the existing "Game-Well" remote alarm monitoring with } \\
\text { alarm displays in the DST farms. }\end{array}$ & $\begin{array}{l}\text { Safety Not required for safety. } \\
\text { Compliance No compliance issues identified. } \\
\text { Privatization No privatization requirements identified. } \\
\text { Conduct of Operations Supports the development of enhanced, } \\
\text { centralized TMACS operation }\end{array}$ \\
\hline \multicolumn{5}{|c|}{ Additional Information } \\
\hline 1. & \multicolumn{4}{|c|}{$\begin{array}{l}\text { Ret: WHC-SD-W314-ES-018 Rev. 0; "DST and DCRT Instrument and Control Systems, Initial Assessment," Dated } \\
\text { November 17, } 1995 \text {. } \\
\text { Discussion: The Gamewell system design and hardware is based on a } 50 \text { vear old building fire alarm system which was modified to interface leak and radiation alarms to } \\
\text { CASS. The Gamewell systems are not functional. The Gamewell uses a mechanical "code wheel" to identify an alarm loop (grouping of leak and radiation alarm } \\
\text { elements) which must be manually reset after each event. The Gamewell system interface with CASS uses unique Hanford designed hardware of which there are no spares } \\
\text { and which has maintenance problems.. }\end{array}$} \\
\hline 2. & \multicolumn{4}{|c|}{$\begin{array}{l}\text { Ref: WHC-SD-W314-ER-002, Rev. 0; 241-AW Tank Farm Upgrades; August } 1995 \text {. } \\
\text { Discussion: Individual leak detectors cannot be readily or remotely identified resulting in time consuming tank farm walkdowns to determine the cause of the alarm. } \\
\text { Greater versatility and reliability will be required in the future when the number of waste transfers increases. Additionally, the Gamewell is obsolete, is difficult to } \\
\text { maintain an obtain spare parts, and does not adequately support current operations. }\end{array}$} \\
\hline 3. & \multicolumn{4}{|c|}{ Discussion: The Gamewell system does not allow identification of individual leak sensing elements. } \\
\hline
\end{tabular}


HNF-SD - W314-RPT- 003

Revision 2

\begin{tabular}{|c|c|c|c|}
\hline Section & Category & Description & Requirement \\
\hline $\begin{array}{l}\text { USSR } 2.2 .3 \\
\text { TWRS SE } 4.2 .1 \\
\text { W-314 SE } \\
4.2 .1 .1 \\
4.2 .1 .3\end{array}$ & $\begin{array}{l}\text { Instrumentation } \\
\text { and Control }\end{array}$ & $\begin{array}{l}\text { Connect selected existing alarms from SST farms and } \\
\text { miscellaneous hazardous facilities for input to the TMACS. }\end{array}$ & $\begin{array}{l}\text { Safety Not required for safety. } \\
\text { Compliance DOE } 5820.2 \mathrm{~A} \text {, alarm and monitoring system } \\
\text { requirements. } \\
\text { Privatization No privatization requirements identified. } \\
\text { Conduct of Operations TMACS is a supervisory monitor system } \\
\text { which has been installed as part of the tank farms safety initiative. } \\
\text { TMACS has significantly improved conduct of operations and } \\
\text { has reduced surveillance costs. Since TMACS is installed in } \\
\text { most of the tank farms, future work should capitalize on these } \\
\text { recent improvements by using it as the basis of the overall central } \\
\text { monitoring system.. }\end{array}$ \\
\hline \multicolumn{4}{|c|}{ Additional Information } \\
\hline $\begin{array}{l}\text { Discus } \\
\text { require }\end{array}$ & \multicolumn{3}{|c|}{$\begin{array}{l}\text { Discussion: SST and other facilities which continue to be monitored should have selected signals connected to a central alarm monitoring system to reduce the man hours } \\
\text { required to go to each location to monitor the alarms.. }\end{array}$} \\
\hline
\end{tabular}


HNF-SD-W314-RPT- 003

Revision 2

\begin{tabular}{|c|c|c|c|}
\hline Section & Category & Description & Requirement \\
\hline $\begin{array}{l}\text { USSR } 2.2 .3 \\
\text { TWRS SE } 4.2 .1 \\
\text { W-314 SE } \\
4.2 .1 .1 \\
4.2 .1 .3\end{array}$ & $\begin{array}{l}\text { Instrumentation } \\
\text { and Control }\end{array}$ & Move selected monitor and controls from the $242-\mathrm{S}$ control room. & $\begin{array}{l}\text { Safety Not required for safety. } \\
\text { Compliance No compliance requirements identified. } \\
\text { Privatization No privatization requirements identified. } \\
\text { Conduct of Operations Relocation of the identified signals from } \\
\text { the } 242-S \text { control room will allow this building to be transferred } \\
\text { to the D\&D contractors, thus reducing operation and other } \\
\text { support costs. }\end{array}$ \\
\hline \multicolumn{4}{|c|}{ Additional Information } \\
\hline $\begin{array}{l}\text { Discus } \\
\text { from tl }\end{array}$ & \multicolumn{3}{|c|}{$\begin{array}{l}\text { Discussion: } 200 \text { West SST and other facility signals that presently terminate in the } 242-S \text { control room and continue to be used should be moved completely out and away } \\
\text { from the } 242-S \text { control room to facilitate it's eventual demolition. }\end{array}$} \\
\hline
\end{tabular}


HNF - SD - W3 14-RPT- 003

Revision 2

\begin{tabular}{|c|c|c|c|}
\hline Section & Category & Description & Requirement \\
\hline $\begin{array}{l}\text { USSR } 2.2 .4 \\
\text { TWRS SE } 4.2 .1 \\
\text { W-314 SE } \\
4.2 .1 .1 \\
4.2 .1 .3\end{array}$ & Electrical & $\begin{array}{l}\text { Replace existing MCCs and vent and heater control panels with } \\
\text { new units in the } 241-A Z \text { and } 241-A Z \text { Tank Farms. }\end{array}$ & $\begin{array}{l}\text { Safety Not required for safety. } \\
\text { Compliance No compliance requirements identified. } \\
\text { Privatization No privatization requirements identified. } \\
\text { Conduct of Operations Assure electrical systems will meet OSR } \\
\text { requirements for the life of the facility. }\end{array}$ \\
\hline \multicolumn{4}{|c|}{$\begin{array}{l}\text { Additional Information } \\
\text { 1. Ref: WHC-SD-W314-ES-020, Rev. 0, "DST \& DCRT Tank Far Electrical Distribution Systems Initial Assessment" } \\
\text { Discussion: For 241-AY and 24l-AZ tank farms, the OSR limits the maximum down time for the operation of the primary exhaust fans and stack monitoring system. Due } \\
\text { to this limitation, maintenance on electrical equipment has not been performed well. As a result. the condition of existing electrical equipment is poor. The replacements, } \\
\text { along with modifications under project W-030 to provide backup power will assure meeting the OSR requirement for the life of the facility. }\end{array}$} \\
\hline
\end{tabular}


HNF - SD-W3 14-RPT-003

Revision 2

\begin{tabular}{|c|c|c|c|}
\hline Section & Category & Description & Requirement \\
\hline $\begin{array}{l}\text { USSR } 2.2 .4 \\
\text { TWRS SE } \\
4.2 .1 \\
\text { W-3.3 SE } \\
4.2 .1 .1 \\
4.2 .1 .3 \\
\end{array}$ & Electrical & $\begin{array}{l}\text { Upgrade and/or provide backup power system for the primary } \\
\text { ventilation system and stack monitors for Tank Farms } 24 \text { l-AN. AP, } \\
\text { and AW. }\end{array}$ & $\begin{array}{l}\text { Safety Not required for safety. } \\
\text { Compliance DOE } 5820.2 \mathrm{~A} \text {, normal and backup electrical power. } \\
\text { Privatization No privatization requirements identified. } \\
\text { Conduct of Operations Assure electrical systems will meet OSR } \\
\text { requirements for the life of the facility. }\end{array}$ \\
\hline Additional I & \multicolumn{3}{|c|}{$\begin{array}{l}\text { Ref: WHC-SD-W314-ES-020, Rev. 0, "DST \& DCRT Tank Far Electrical Distribution Systems Initial Assessment" } \\
\text { Discussion: The OSR limits the maximum down time for the operation of the primary exhaust fans and stack monitor systern. The backup power system is required to } \\
\text { allow the primary exhaust fans and stack monitor to operate while maintenance is performed on the tank farm electrical equipment, without affection the OSR requirement. }\end{array}$} \\
\hline
\end{tabular}


HNF - SD - W314-RPT- 003

Revision 2

\begin{tabular}{|c|c|c|c|}
\hline Section & Category & Description & Requirement \\
\hline $\begin{array}{l}\text { USSR } 2.2 .4 \\
\text { TWRS SE } \\
4.2 .1 \\
\text { W-314 SE } \\
4.2 .1 .1 \\
4.2 .1 .3\end{array}$ & Electrical & $\begin{array}{l}\text { Replace existing feeder of } 244-S \text { by providing a new pad-mounted } \\
13.8 \mathrm{kV} \text { transformer. }\end{array}$ & $\begin{array}{l}\text { Safety Not required for safety. } \\
\text { Compliance DOE } 5820.2 \mathrm{~A} \text {, normal and backup electrical power. } \\
\text { Privatization No privatization requirements identified. } \\
\text { Conduct of Operations Assure electrical systems will meet OSR } \\
\text { requirements for the life of the facility. }\end{array}$ \\
\hline \multicolumn{4}{|c|}{ Additional Information } \\
\hline \multicolumn{4}{|c|}{$\begin{array}{l}\text { Ref: WHC-SD-W314-ES-020, Rev. 0, "DST \& DCRT Tank Far Electrical Distribution Systems Initial Assessment" } \\
\text { Discussion: The } 2.4 \mathrm{kV} \text { supply system for this feeder will be discontinued by the utilities to standardize the distribution system voltage to a } 13.8 \mathrm{kV} \text { system. }\end{array}$} \\
\hline
\end{tabular}


HNF-SD-W3 14-RPT-003

Revision 2

\begin{tabular}{|c|c|c|c|}
\hline Section & Category & Description & Requirement \\
\hline $\begin{array}{l}\text { USSR } 2.2 .4 \\
\text { TWRS SE } \\
4.2 .1 \\
\text { W-314 SE } \\
4.2 .1 .1 \\
4.2 .1 .3\end{array}$ & Electrical & Spare main circuit breakers for AN, and AW Tank Farms. & $\begin{array}{l}\text { Safetv Not required for safety. } \\
\text { Compliance No compliance issues identified. } \\
\text { Privatization No privatization requirements identified. } \\
\text { Conduct of Operations Provide power tlexibility in support of } \\
\text { preventive maintenance to ensure serviceability for the life of the } \\
\text { facility. }\end{array}$ \\
\hline \multicolumn{4}{|c|}{ Additional Information } \\
\hline $\begin{array}{l}\text { R } \\
\text { D } \\
\text { te }\end{array}$ & \multicolumn{3}{|c|}{$\begin{array}{l}\text { Ref: WHC-SD-W314-ES-020, Rev. 0, "DST \& DCRT Tank Far Electrical Distribution Systems Initial Assessment" } \\
\text { Discussion: The spare main circuit breaker for the switchgear is required to allow preventive maintenance on the existing breaker, which will ensure proper trip setting and } \\
\text { testing to protect the electrical system. }\end{array}$} \\
\hline
\end{tabular}


HNF-SD-W314-RPT- 003

Revision 2

\begin{tabular}{|c|c|c|c|}
\hline Section & Category & Description & Requirement \\
\hline $\begin{array}{l}\text { USSR } 2.2 .4 \\
\text { TWRS SE } \\
4.2 .1 \\
\text { W-314 SE } \\
4.2 .1 .1 \\
4.2 .1 .3 \\
\end{array}$ & Electrical & $\begin{array}{l}\text { Bring SST power systems to code with standardized grounding to } \\
\text { support existing lights, service. }\end{array}$ & $\begin{array}{l}\text { Safety Not required for safety. } \\
\text { Compliance DOE } 5820.2 \mathrm{~A} \text {, normal and backup electrical power. } \\
\text { Privatization No privatization requirements identified. } \\
\text { Conduct of Operations Assure electrical systems will meet OSR } \\
\text { requirements for the life of the facility. }\end{array}$ \\
\hline \multicolumn{4}{|c|}{ Additional Information } \\
\hline 1. & $\begin{array}{l}-W 314-E S \\
\text { e } 2.4 \mathrm{kVs}\end{array}$ & $\begin{array}{l}\text { ev. 0, "DST \& DCRT Tank Far Electrical Distribution Systems Init } \\
\text { ystem for this feeder will be discontinued by the utilities to standar }\end{array}$ & $\begin{array}{l}\text { Assessment" } \\
\text { the distribution system voltage to a } 13.8 \mathrm{kV} \text { system. }\end{array}$ \\
\hline
\end{tabular}


HNF-SD - W3 14-RPT- 003

Revision 2

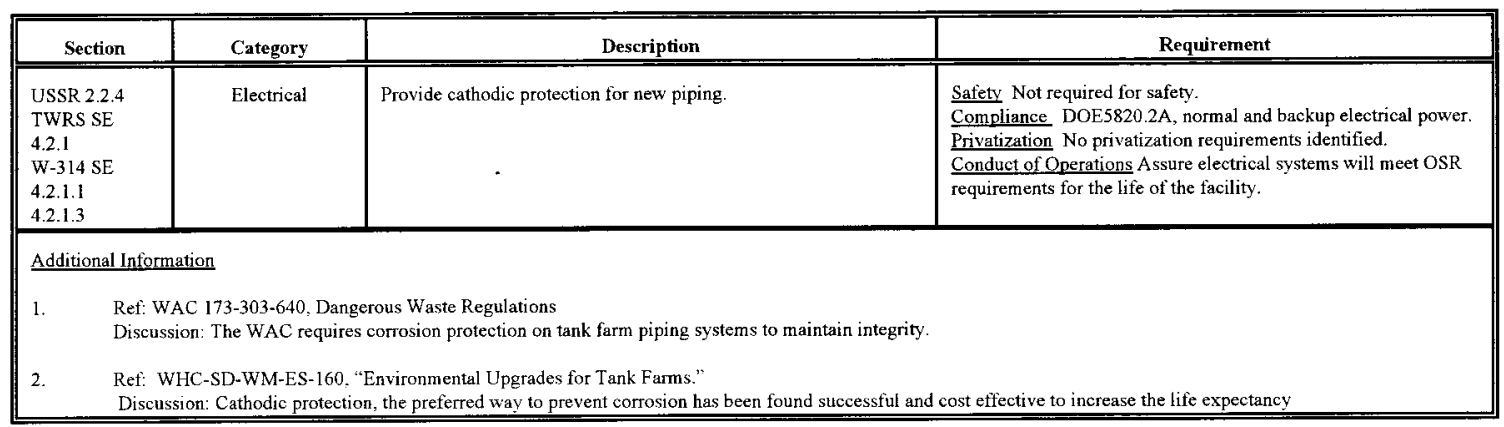


HNF-SD-W314-RPT-003

Revision 2

\begin{tabular}{|c|c|c|c|}
\hline Section & Category & Description & Requirement \\
\hline $\begin{array}{l}\text { USSR } 2.2 .4 \\
\text { TWRS SE } \\
4.2 .1 \\
\text { W-3.14 SE } \\
4.2 .1 .1 \\
4.2 .1 .3\end{array}$ & Electrical & $\begin{array}{l}\text { Provide freeze protection for seal pots, drainage systems, and } \\
\text { piping (if required) installed by W- } 314 \text {. }\end{array}$ & $\begin{array}{l}\text { Safety Not required for safety. } \\
\text { Compliance No compliance issues identified, } \\
\text { Privatization No privatization requirements identified. } \\
\text { Conduct of Operations Assure piping systems are protected from } \\
\text { seasonal cold weather. }\end{array}$ \\
\hline \multicolumn{4}{|c|}{ Additional Information } \\
\hline $\mathrm{N} / \mathrm{A}$ & & & \\
\hline
\end{tabular}




\section{DISTRIBUTION SHEET}

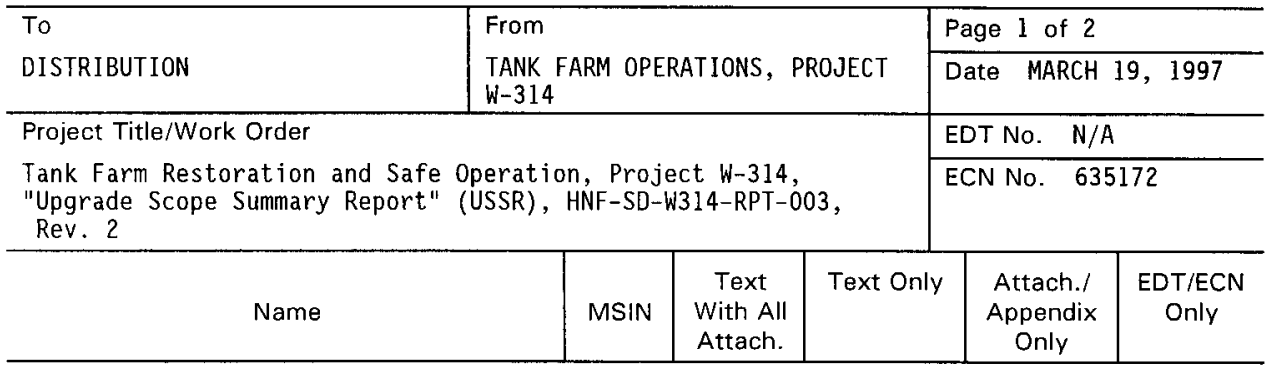

DOE-RL

J. E. Navarro

57-54 $X$

G. M. Ramin

S7-54

S7-54

$\hat{x}$

M. L. Ramsay

$x$

Fluor Daniel Hanford, Inc.

D. J. Ashley

S7-40

S. J. Dechter

R1-05

S. U. Zaman

B1-19

$x$

$x$

Fluor Daniel Northwest, Inc.

H. M. Chafin

J. T. Koberg

M. D. Rickenbach

R3-25 $X$

G3-12 $\quad X$

Lockheed Martin Hanford Corporation
J. J. Badden
W. D. Bancroft
T. W. Bohan
D. E. Bowers
J. G. Burton
R. W. Dodd
A. F. Erhart
B. G. Erlandson
R. W. Jacobson
J. D. McDonald
R. L. Nelson
D. R. Nunamaker
R. J. Shupe
W. T. Thompson
J.M. Thurman

G3-12

T4-07

S5-07

S5-04

S6-01

T4-07

S5-07

R2-50

$\mathrm{R} 2-36$

$\mathrm{R} 1-09$

$\mathrm{R} 2-50$

R3-47

$\mathrm{T} 4-07$

R2-82

G3-21

$\mathrm{R} 2-88$

$R]-51$

Lockheed Martin Services, Inc.

Project Files

G3-11

$x$

$X$

$x$

$X$

$x$

$x$

$X$

$X$

$X$ (3 Copies)

Numatec Hanford Corporation
K. A. Boes
J. D. Galbraith
P. A. Haine
D. L. McGrew
W. W. Rutherford

$\begin{array}{ll}\text { R3-25 } & X \text { (3 Copies) } \\ \text { H5-49 } & X \\ \text { R3-47 } & X \\ \text { R3-25 } & X \\ \text { R3-25 } & X\end{array}$


HNF-SD-W314-RPT-003, Rev 2.

Page 2 of 2

DISTRIBUTION SHEET (continued)

DE \& S Hanford Company

D. G. Baide

G. L. Dunford

S. H. Rifaey

M. S. Tiffany

L. A. Williamson

S2-48

T4-07

R1-56

R $1-49$

Rl-49

$X$
$X$
$X$
$X$
$X$

Rust Federal Services of Hanford, Inc.

J. E. Geary

$56-71$

$56-71$

R. J. Nicklas

$56-72$

$x$
$X$
$X$

